\title{
Chapter 1 \\ Agrobacterium rhizogenes-Mediated Transformation and Its Biotechnological Applications in Crops
}

\author{
Ibrahim Ilker Ozyigit, Ilhan Dogan and Ebru Artam Tarhan
}

\begin{abstract}
The history of Agrobacterium-related plant biotechnology goes back for more than three decades with the discovery of molecular mechanisms of crown gall disease in plants. After 1980s, gene technologies began developing rapidly and today, related with the improved gene transfer methods, plant biotechnology has become one of the most important branches in science. Till now, the most important genes related with agricultural affairs have been utilized for cloning of plants with the deployment of different techniques used in genetic engineering. Especially, Agrobacterium tumefaciens was used extensively for transferring desired genetic materials to plants rapidly and effectively by the researchers to create transgenic plants. Recognition of the biology of Agrobacterium species and newly developed applications of their T-DNA systems has been a great step in plant biotechnology. This chapter provides the reader with extensive information on A. rhizogenes which is responsible for the development of hairy root disease in a wide range of dicotyledonous plants and its T-DNA system. This knowledge will be useful in improving utilization of crops and the formulation of new and up-graded transgenic based food products.
\end{abstract}

\section{Introduction}

The increase in demand for food is dramatic with an expanding population growth in the world. According to latest projections, continued increase at the current rate of the population is expected to reach between 7.5 and 10.5 billion by

\footnotetext{
I. I. Ozyigit $(\bowtie) \cdot$ E. Artam Tarhan

Department of Biology, Faculty of Science \& Arts, Marmara University,

Goztepe, 34722 Istanbul, Turkey

e-mail: ilkozyigit@marmara.edu.tr

I. Dogan

Department of Molecular Biology and Genetics, Faculty of Science, Izmir Institute of Technology, 35430 Urla, Izmir, Turkey

e-mail: ilhandogan@iyte.edu.tr

E. Artam Tarhan

e-mail: eartamtarhan@gmail.com
} 
2050 (Census 2012). Climate changes in terms of shifting weather patterns will result in decreased water availability and in conjunction with this, providing food for this inevitable future population size will be a very hard task without adding new arable lands (Milly et al. 2005). To deal with this challenge one of the major solutions is plant breeding, which has been used since ancient times in order to create desired genotypes and phenotypes for specific objectives. The main goals of conventional plant breeding are improvement of crop yield and quality, agricultural convenience and resistance to the parasites. While the conventional plant breeding efforts used in the past were sufficient, nowadays with the increasing demand additional and supplementary technology necessities emerged (Gepts 2002). As a result of industrial revolution and its reflection to the biological and agricultural sciences, plant biotechnology reached spectacular success with understanding of how genes operate and function in plant. The first genetically modified crops were obtained in the early 1980 s by using Agrobacterium tumefaciens following the plant regeneration systems, production of novel chimeric genes and transformation vectors. Multidisciplinary studies of academic institutions and agricultural seed companies took the leadership on genetic engineering and biotechnological progresses of crop plants (Özcan et al. 2004). Although, many political, regulatory, ethical and religious obstacles are still present, the adoption rate of crop biotechnology in the area of agriculture is high at global level. Crop biotechnology involves a different set of technologies such as industrial use of recombinant DNA, cell fusion and tissue engineering. Agrobacteri$u m$-mediated transformation has always been the most commonly used method for novel transgenic technologies. Till now, a number of commercially valuable crops like tomato, potato, rice, wheat, maize, cotton, soybean, alfalfa, barley, carrot, sugarcane, pepper and broccoli were obtained using Agrobacterium-mediated transformation (Ozyigit 2012).

\section{Characteristics of Agrobacterium rhizogenes}

Certain bacterial species are capable of transferring some of their genes to higher plants ending up with insertion and permanent integration in the nuclear genome (Broothaerts et al. 2005; Kumar et al. 2006). Members of genus Agrobacterium are widely known for their ability of forming a wide variety of different neoplastic diseases, including crown gall ( $A$. tumefaciens and $A$. vitis), hairy root (A. rhizogenes) and cane gall (A. rubi) (Gelvin 2009; Ozyigit 2012). Among them, the first identified one was $A$. rhizogenes (formerly Phytomonas rhizogenes) in 1930s belonging to the family Rhizobiaceae in the alpha-2 subclass of Proteobacteria (Riker et al. 1930; Hildebrand 1934; Conn 1942; White 1972; Kersters and De Ley 1984; Woese et al. 1984; Willems and Collins 1993).

A. rhizogenes is a rod-shaped Gram-negative, non-spore forming $(0.6-1 \mu \mathrm{m}$ by $1.5-3.0 \mu \mathrm{m}$ in size) soil bacterium that occurs singly or in pairs and is motile by means of one to six peritrichous flagella (Conn 1942; Meyer et al. 2000; Tzfira and 
Fig. 1.1 Scanning electron micrograph of attachment of Agrobacterium rhizogenes strain R1000 to sunflower (Helianthus annuus L.) cotyledonary node cell

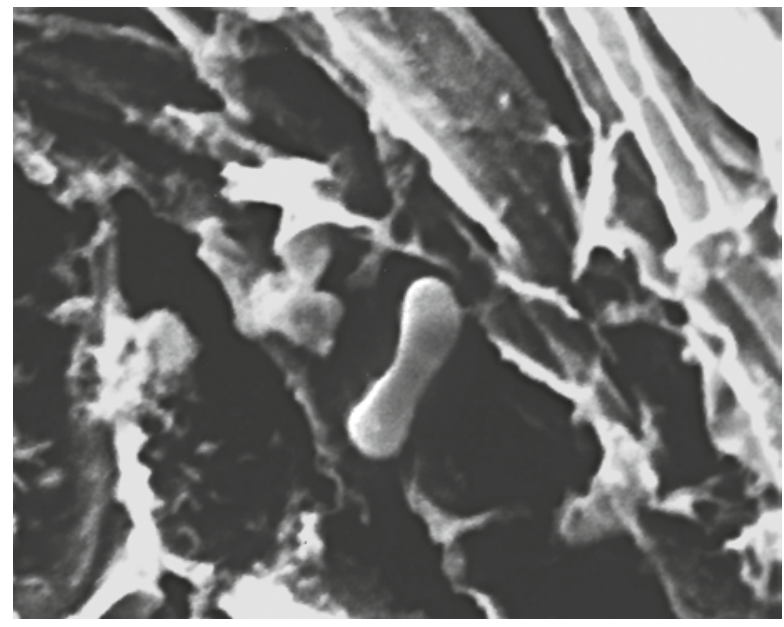

Citovsky 2000; Giri and Giri 2007; Murugesan et al. 2010) (Fig. 1.1). It is a close relative of the better known A.tumefaciens, which is the best-characterized species among the genus Agrobacterium (Rao 2009; Ozyigit 2012) (Fig. 1.1).

All $A$. rhizogenes strains are characterized by the presence of a large root inducing ( $\mathrm{Ri})$ plasmid containing a highly conserved "core" DNA region required for hairy root formation (Filetici et al. 1987; Gelvin 2003; Veena and Taylor 2007). Like the crown gall disease, which is caused by A. tumefaciens (Ream 2002; McCullen and Binns 2006; Ozyigit 2012) A. rhizogenes causes hairy root (root-mat) disease in infected plants through genetic transformation (Weller and Stead 2002; Weller et al. 2005).

\section{Hairy Root Disease}

The "hairy root" is the term first used in 1900 by Stewart et al. (as quoted by Hildebrandt 1934). The distinctive symptom of hairy root disease is the formation of a mass of roots. Following the $A$. rhizogenes infection, hairy root formation occurs as a result of protruding large numbers of small roots as fine hairs directly from the infection site (Chandra 2012) (Fig. 1.2). Besides the plagiotropic root growth, hairy-root disease is characterized as short internodes, a high degree of lateral branching, wrinkled leaves, reduced apical dominance, reduced fertility, profusion of root hairs, abnormal flower production, advanced flowering, increased number of flowers, enhanced growth rates and changed secondary metabolite accumulation (Ackermann 1977; Tepfer 1983; Balandrin et al. 1985; Charlwood and Charlwood 1991; Pellegrineschi et al. 1994; Flores et al. 1999; Lee et al. 2001; Keil 2002; Casanova et al. 2004; Veena and Taylor 2007) (Fig. 1.2). 

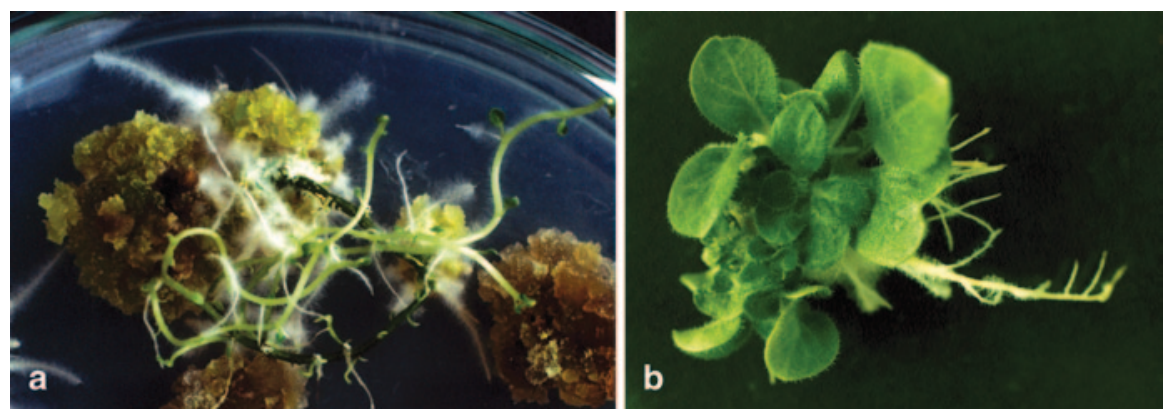

Fig. 1.2 Hairy root formation induced by A. rhizogenes strain 8196 in potato (Solanum tuberosum L.) callus cultures (a), regenerated tobacco (Nicotiana tabacum L.) plantlets (b). (From Arican)

In nature, when plants are suffering from wounds, phenolic compounds are released from wounded sides and that cause attraction for A. rhizogenes. The bacterium moves toward the wounded sites by chemotaxis and infect plant cells. Subsequent infection at wound site followed by transfer of a particular DNA segment (T-DNA) from the root-inducing (Ri) plasmid (pRi) of the bacteria (Kumar et al. 2006). A. rhizogenes-induced roots have the unique property of being able to grow in vitro without exogenous plant growth regulators (Lee et al. 2001; Rao and Ravishankar 2002). With this unique ability, by the utilization of $A$. rhizogenes strains in in vitro plant organ cultures, broad range difficulties were eliminated and as a result, fast growing organs with the capable of producing extensive branching and main metabolites even higher than the mother plant or new metabolites undetected in the mother plant or in other kinds of in vitro cultures were generated (Doran 2002; Nader et al. 2006; Bensaddek et al. 2008).

Over the three decades, hairy roots have been applied in a wide range of fundamental studies of plant biochemistry, molecular biology, and physiology, as well as for agricultural, horticultural, and large-scale tissue culture purposes (Doran 2002). In general, hairy root cultures have been used extensively in root nodule research (Diaz et al. 1989; Quandt et al. 1993; Diouf et al. 1995; Hu and Du 2006; Hirotaka and Hiroshi 2003; Aarrouf et al. 2012), production of artificial seeds (Uozumi and Kobayashi 1997), plant secondary metabolites and proteins (Aarrouf et al. 2012), plant breeding and plant improvement, experimental systems to study responses to chemicals (Downs et al. 1994; Mugnier 1997), plant morphology and development (Bandyopadhyay et al. 2007; Turgut-Kara and Ari 2008; Hasancebi et al. 2011; Aarrouf et al. 2012), detoxifing environmental pollutants (Rugh 2001), validate and analyze the functions of genes conferring resistance to root specific pathogens (Remeeus et al. 1998; Hwang et al. 2000; Alpizar et al. 2006; Aarrouf et al. 2012) and study interactions with other organisms such as nematodes (Kifle et al. 1999), mycorrhizal fungi and root pathogens (Mugnier 1997; Christey 2001). Besides these sights, enhanced rooting in plants helps establishment or surviving transplant shocks or abiotic stress like drought, salinity and heavy metal stress (Bulgakov, 2008; Li et al. 2011). 
Fig. 1.3 Scanning Electron Micrograph of $A$. rhizogenes strain 8196 colonizing sunflower (H. annuus L.) cotyledonary node cell wall

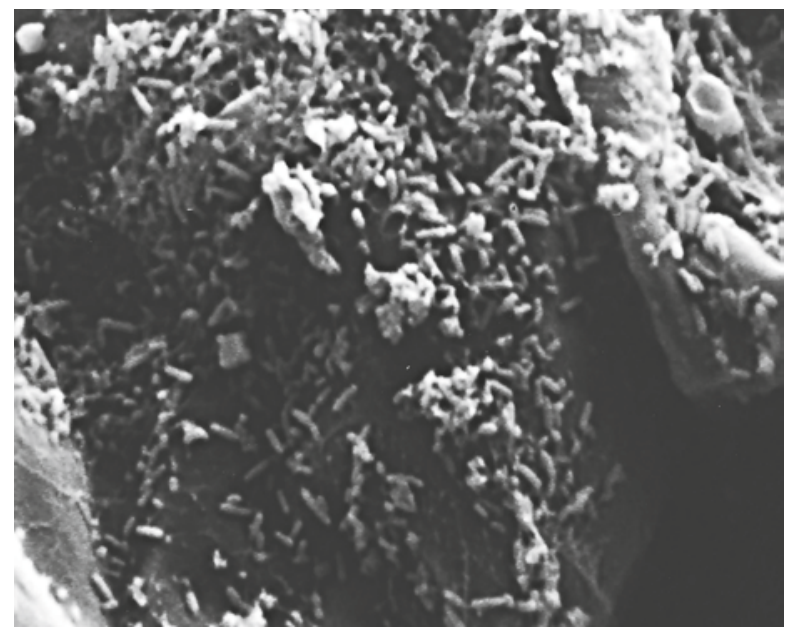

\section{The Mechanism of Hairy Root Formation}

The overall process of hairy roots disease by $A$. rhizogenes wild strains is defined by the following four steps. Chimiotactism is the first step leading to induced movement of Agrobacterium towards to the plant cells. The following step is binding of Agrobacterium to the surface components of the cell wall (Fig. 1.3). After binding, transfer and integration of the transfer-DNA (T-DNA) into the plant genome is completed. The last step is subsequent induction of root formation and growth (Zupan et al. 1996). The information gained in the first three steps is better understood because of the similarities in biological processes and existing models of pathogenesis provided by extensive studies of A. tumefaciens stain C58 (Tomilov et al. 2007; Abarca-Grau et al. 2011). The compositions as well as structures are broadly similar for Ri and the Ti plasmids from A. rhizogenes and A. tumefaciens, respectively (Gelvin 2003; Ozyigit 2012) (Fig. 1.3).

Comparative studies showed a high degree of homology between $\mathrm{Ri}$ and $\mathrm{Ti}$ plasmids indicating that there are conserved regions between the two types of plasmids. This shows general mechanisms such as activation, processing, and movement of the T-DNA from the bacteria to the plant cell are highly sustained. A segment in both Ri and Ti plasmids called T-DNA consists of highly homologous 24-bp direct repeats known as border sequences (Yadav et al. 1982; Filichkin and Gelvin 1993; Ziemienowicz 2001; Veena and Taylor 2007; Chandra 2012). During infection with Agrobacterium, T-DNA is transferred from the bacterium to the plant cell (Rao et al. 2009). The wild-type T-DNA encodes oncogenes and opine catabolism genes, which cause neoplastic growth of tissues and the production of opines (Guyon et al. 1980, 1993; Costantino et al. 1994; Gaudin et al. 1994; Weising and Kahl 1996; Hong et al. 1997; Lee et al. 2001; Rao and Ravishankar 2002; Veena and Taylor 2007). Also, another segment known as the virulence (vir) region in the Ti-plasmid is involved in transferring of DNA into the plant genome (Bulga- 
kov et al. 2004). Hairy roots are capable of growing in the absence of exogenous plant hormones on the plant cells due to the presence of T-DNA. Agrobacterium species are highly adapted for sophisticated parasitic relationship with host plants and thus found to establish a unique ecological niche by genetically engineering (Vilkar et al. 1987).

\section{Gall Proteins}

One of the similarities of Ri and Ti plasmid is that bearing nearly identical organization of the vir operons (Zhu et al. 2000). Only noticeable difference can be seen is neither genomes nor Ri plasmids of $A$. rhizogenes contains virE1 and virE2 genes (Moriguchi et al. 2001; Hodges et al. 2004). As known from studies about $A$. tumafaciens VirE2 is a single-stranded DNA binding protein and VirE1 acts as a chaperone of VirE2. The VirE2 covers single-stranded T-DNA (T-strands) from nuclease attack (Rossi et al. 1996; Ozyigit 2012) and involves nuclear import of T-DNA to the plant cells (Yusibov et al. 1994; Rossi et al. 1996; Zupan et al. 1996; Gelvin 1998). virE genes play critical roles in pathogenesis of $A$. tumefaciens (Christie et al. 1988; Citovsky et al. 1992; Ward and Zambryski 2001; Duckely and Hohn 2003; Ozyigit 2012). However, the absence of virE genes or no other homolog genes in the $A$. rhizogenes genome clearly shows that virE genes are not necessary in the mechanism of hairy root induction (Moriguchi et al. 2001). Recent studies imply that despite sharing no homology, the GALLS gene located on the Ri plasmid can substitute VirE2 function in A. tumefaciens (Hodges et al. 2004). GALLS protein differs from VirE2 with ATP-binding and helicase motifs resembling to those in TraA protein involved in conjugation. Both GALLS and VirE2 contain nuclear localization sequences and a C-terminal type IV secretion signal. Mutations in these domains lead to loss of GALLS ability to substitute for VirE2 (Sinkar et al. 1988; Hodges et al. 2006). However, mechanism of GALLS protein in $A$. rhizogenes is still not fully known. All these facts reveal that in spite of differences in their virulence systems, the Ti and $\mathrm{Ri}$ plasmids are share a common ancestor. However, the way of T-DNA transfer and those other variations in T-DNA processing also show signs of independent evolution from each other. Current understanding of the molecular bases of the differences between hairy root and gall formation will be accelerated by further studies on genome sequencing and comparison of various Agrobacterium strains (Hodges et al. 2006).

\section{Ri Plasmid}

Ri plasmid in all $A$. rhizogenes strains has a region known as T-DNA which carries genes (rol-genes) involved in root initiation and development and genes essential for opine biosynthesis (Slightom et al. 1986; Hansen et al. 1994a). Agrobacterium 


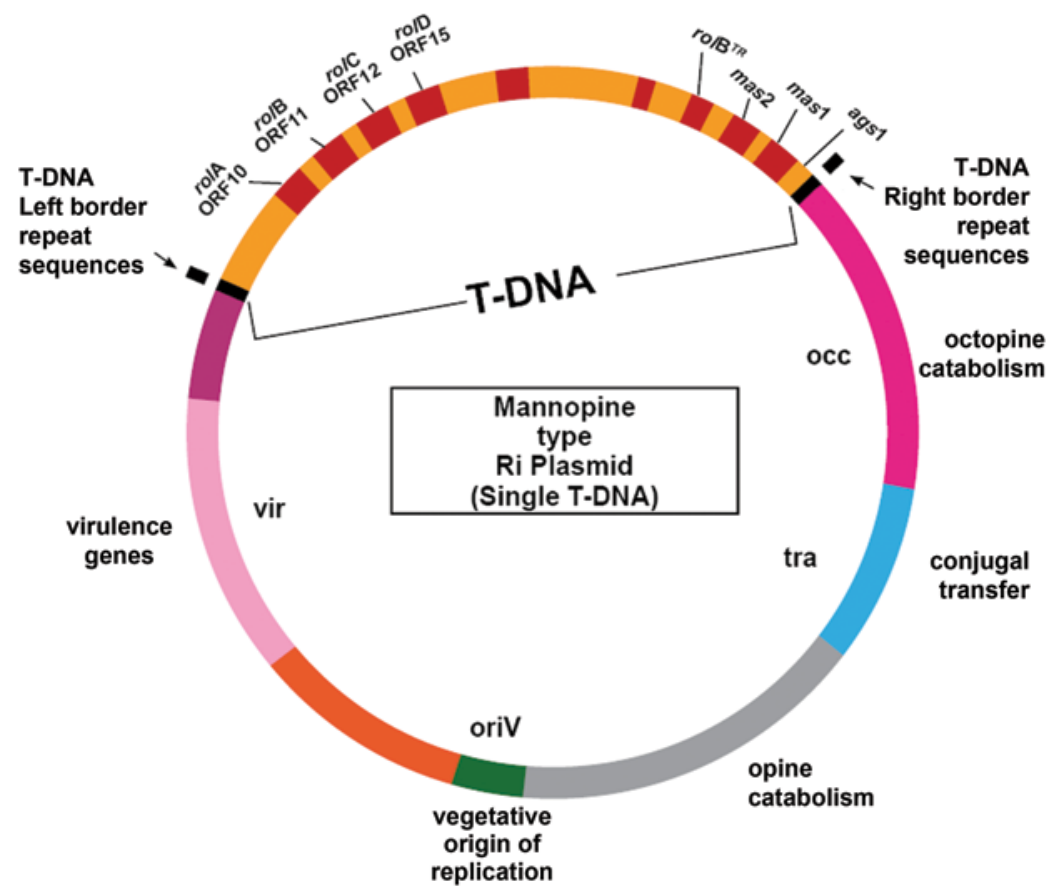

Fig. 1.4 Schematic representation of Mannopine type Ri plasmid of A. rhizogenes

T-DNA makes up a small region (approximately $200 \mathrm{~kb}$ ) of Ti/Ri plasmids which are involved in functions not only for Ti/Ri plasmid conjugation, opine synthesis and catabolism, but also initiation, transfer and integration of the T-DNA (Ozyigit 2012). Although T-DNA contains genes with bacterial origin, these genes have eukaryotic regulatory sequences enabling their expression in infected plant cells (Giri and Narasu 2000). After integration of T-DNA into genomic DNA of the plant cell, T-DNA expresses enzymes that direct the synthesis of unusual amino acid sugar derivatives known as opines, which used by the Agrobacterium as nutrient source (Petit et al. 1983; Dessaux et al. 1992; Gartland 1995; Moyano et al. 1999; Navarrete et al. 2006; Bensaddek et al. 2008; Ozyigit 2012).

There are at least two classes of opines produced by A. rhizogenes strains. One such class is represented by opines of agropine group, and the other class being the agrocinopine group. Most of the A. rhizogenes strains are capable of producing agrocinopine type opines and all or a few strains of producing agropine type opines. The agropine-type opines including agropine, mannopine, agropinic acid and mannopinic acid are produced by the strains known as the agropine-type whereas all agropine-type opines excluding agropine are produced by the strains known as the mannopine-type (Figs. 1.4, 1.5) (White et al. 1982; Petit et al. 1983; Tempe et al. 1984; Savka et al. 1990; Gartland, 1995; Navarrete et al. 2006). 


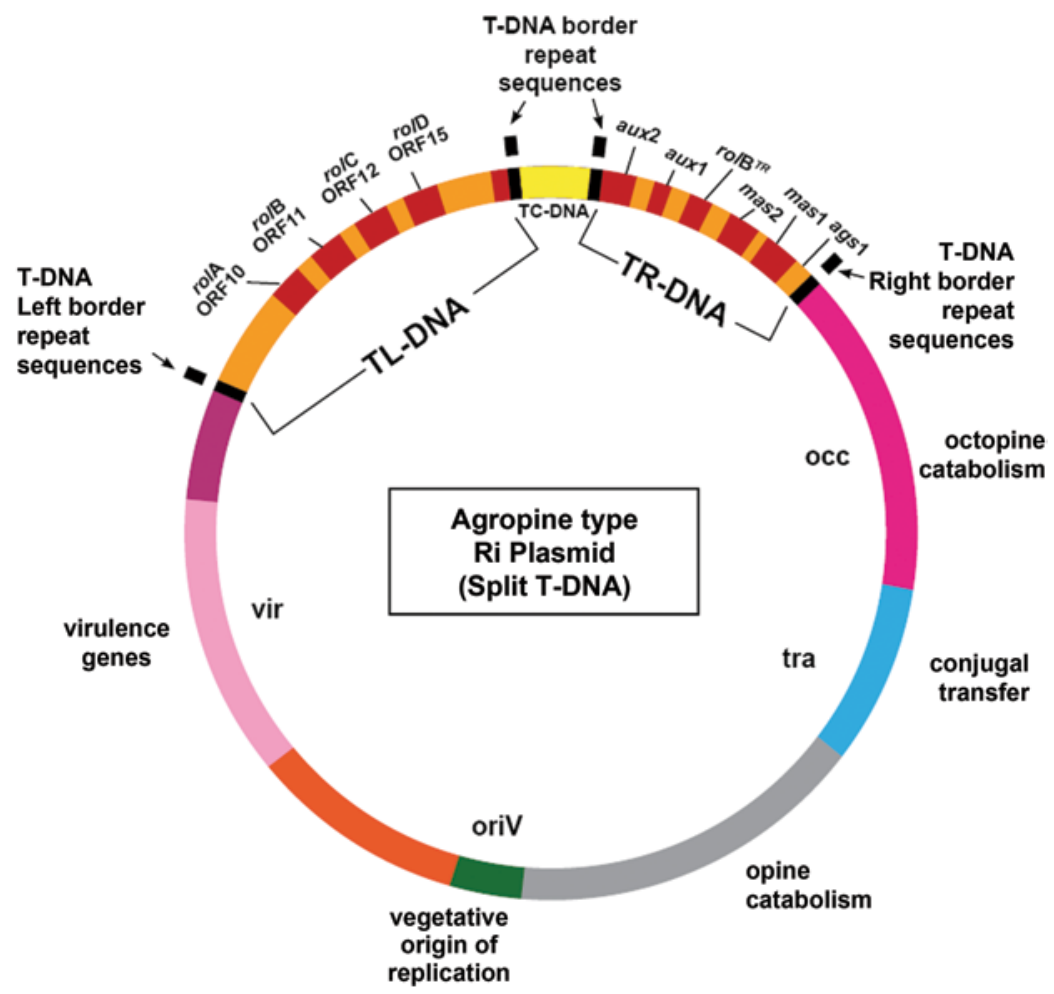

Fig. 1.5 Schematic representation of Agropine type Ri plasmid of A. rhizogenes

The most common $A$. rhizogenes strains which represented by Ri plasmids are agropine-type: pRiA4, pRi1855, pRiHRI, pRi15834, and pRiLBA9402, mannopine-type: pRi8196, cucumopine type: pRi2659 and mikimopine-type pRi1724. Although mikimopine and cucumopine are stereo-isomers, there is no homology between opine biosynthetic genes on the nucleotide level (Filetici et al. 1987; Davioud et al. 1988; Gartland 1995; Ouartsi et al. 2004; Veena and Taylor 2007) (Fig. 1.4).

Among the different known strains of A. rhizogenes, K47, K599 and HRI are hyper-virulent types known to be capable of infecting a broad range of plant hosts. More research on the virulence factors of these strains needs to be done for understanding of whether they are located on the chromosome(s), plasmid(s) or both (Petit et al. 1983; Isogai et al. 1988; Porter 1991; Suzuki et al. 2001). Also, there are differences between $A$. rhizogenes strains in terms of polarity of infection of the plant tissue. For example, root growth can be induced by some strains of $A$. rhizogenes only on the apical surfaces of carrot root discs and yield no detectable outgrowth on the basal surfaces, whereas root proliferation can be induced by others both inoculation of apical and basal surfaces (Cardarelli et al. 1985; Ryder et al. 1985; Capone et al. 1989; Limami et al. 1998). Based on these findings, various $A$. rhizogenes strains were further classified as polar and non-polar types. Agropine 
type strains are non-polar whereas all other strains are polar. Agropine type strains give rise to the formation of the hairy roots regardless of the orientation of the disc and the strains other than agropine type form hairy roots when the disc is placed inverted orientation. The presence of second T-DNA encoding genes responsible for auxin production possibly causes observed variation in the polarity of infection in the plant cells transformed by the agropine-type Ri plasmid (Meyer et al. 2000; Veena and Taylor 2007) (Fig. 1.5).

\section{Ri T-DNA Genes}

Independent transformations of both left T-DNA ( $\mathrm{T}_{\mathrm{L}}$-DNA) (about 15-20 kb) and right T-DNA ( $\mathrm{T}_{\mathrm{R}}$-DNA) (about 8-20 kb) to the plant genome termed as "split" T-DNA are carried out by Agropine strains pRi, whereas mannopine strains only transfer a single T-DNA $\left(\mathrm{T}_{\mathrm{L}}\right.$-DNA). $\mathrm{T}_{\mathrm{L}}$-DNA of $\mathrm{pRi}$ contains the four rol genes, designated as rolA, rolB, rolC and rolD (Schmulling et al. 1988; Petersen et al. 1989; Gelvin 2003; Bensaddek et al. 2008). In Ri plasmid, $T_{L}-D N A$ and $T_{R}-D N A$ are separated from each other by at least $15 \mathrm{~kb}$ of non-integrated DNA, which is represented by T-Central DNA (TC-DNA) as seen in Fig. 1.5.

The phenotype of hairy root is related with the genes whose products act as the determinants located on $T_{L}$-DNA (Tepfer 1984; Taylor et al. 1985; Jouanin et al. 1987b; Nakamura et al. 1988; Schmulling et al. 1988; Sinkar et al. 1988) whereas the genes on the $\mathrm{T}_{\mathrm{R}}$-DNA would only play a role in root induction (Cardarelli et al. 1985; Ryder et al. 1985; Cardarelli et al. 1987a; Smulders et al. 1991). Two fragments, defined as $\mathrm{T}_{\mathrm{L}}$-DNA and $\mathrm{T}_{\mathrm{R}}$-DNA, can be transferred and integrated independently into the plant genome during the infection process. However, the integration capacity of $\mathrm{T}_{\mathrm{L}}$-DNA was much higher than $\mathrm{T}_{\mathrm{R}}$-DNA (Chilton et al. 1982; Costantion et al. 1984; David et al. 1984; Grant et al. 1991; Phelep et al. 1991; Nilsson and Olsson 1997; Holefors et al. 1998; Sevon and Oksman-Caldentey 2002; Kumar et al. 2006; Navarrete et al. 2006; Bensaddek et al. 2008). Furthermore, the present findings imply that a higher number of Ri-T-DNA copies integrated into the plant genome increase the phenotypic effect in the Ri-line (Christensen et al 2008).

\section{T}

It was found that the right T-DNA ( $\mathrm{T}_{\mathrm{R}}$-DNA) contains genes homologous to T-DNA of A. tumefaciens Ti plasmid (Huffman et al. 1984; Jouanin 1984; Vilaine and CasseDelbart 1987; Hansen et al. 1991; Chandra 2012). Among them, the most important genes are those homologous to the tms 1 and $t m s 2$ of the Ti-plasmid. tms 1 and tms 2 genes play important roles in auxin biosynthesis in A. tumefaciens (Inze et al. 1984; Schröder et al. 1984; Thomashow et al. 1984, 1986; Vilaine and Casse-Delbart 1987). Homology, mutagenesis and complementation experiments show that the two 
Fig. 1.6 Schematic representation of gene locations on $\mathrm{T}_{\mathrm{R}}$-DNA

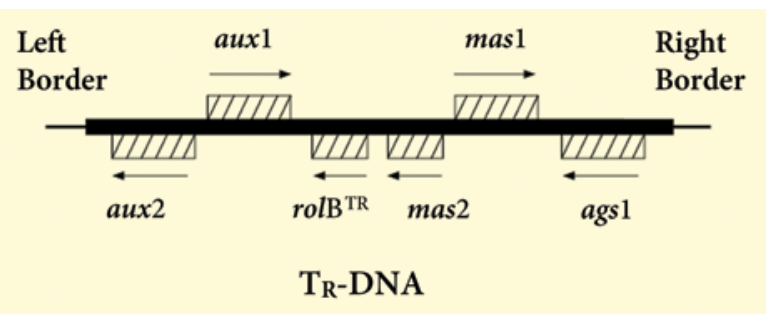

morphogenic loci located on the $T_{R}$-DNA are counterpart of the tms loci located on the Ti plasmids and involve in hairy root tumorigenesis (White et al. 1985). In A. rhizogenes infected Nicotiana glauca tissue, the transcripts of the tms loci of Ri plasmids are found to be similar in size to those transcripts found in the tms region of Ti-plasmids (Willmitzer et al. 1983; Taylor et al. 1985; Vilaine and Casse-Delbart 1987). Similar transcripts were also found in carrot plants regenerated from tissues infected with A. rhizogenes (De Paolis et al. 1985; Vilaine and Casse-Delbart 1987). The root induction is probably due to auxin biosynthesis carried out by the aux loci located on $\mathrm{T}_{\mathrm{R}}$-DNA. The aux loci are found to be homologous to the tms loci of $A$. tumefaciens T-DNA (Vilaine and Casse-Delbart 1987).

aux $1, a u x 2, \operatorname{rol} \mathrm{B}^{\mathrm{TR}}$, mas $1, \operatorname{mas} 2$, and ags genes located on the $\mathrm{T}_{\mathrm{R}}-\mathrm{DNA}$ are responsible for the biosynthesis of agropine and auxin, which cause differences in hairy root growth and morphology when compared to non-transformed roots (Fig. 1.6). It was also reported that the presence of these genes on transformed plant cells caused increase auxin sensitivity (Grant et al. 1991; Lambert and Tepfer 1992; van der Salm et al. 1997; Hansen et al. 1997; Meyer et al. 2000; Alpizar et al. 2006; Nemoto et al. 2009).

Sequence analysis revealed two open reading frames corresponding to proteins of 749 amino acids as aux 1 gene protein and 466 amino acids aux2 gene protein (De Paolis et al. 1985; Camilleri and Jouanin 1991; Gaudin and Jouanin 1995; Christensen et al. 2008; Chandra 2012). Auxin biosynthetic pathway comprises two steps. The $t 2 m$ (tryptophan 2- monooxygenase) gene product encoded by the aux 1 catalyzes the conversion of tryptophan to indole-3-acetamide (IAM) (Comai and Kosuge 1982; Van Onckelen et al. 1986; Camilleri and Jouanin 1991). Then, IAM is converted to indole-3-acetic acid (IAA) by IAM hydrolase, the product of the aux2 (Jouanin 1984; Schröder et al. 1984; Thomashow et al. 1984). The T-DNA of mannopine, cucumopine and mikimopine type strains in Ri plasmids do not carry aux genes. Since these strains are still capable to induce a "hairy-root" phenotype, it can be said that the presence of the aux genes on $\mathrm{T}_{\mathrm{R}}$-DNA is not necessary to generate hairy root phenotype. It has been demonstrated that the aux genes are required to support the "hairy root" phenotype and to extend the host range of the bacterium (White et al. 1985; Cardarelli et al. 1987b; Hansen et al. 1991; Sevon and OksmanCaldentey 2002).

Hybridization experiments also revealed that the genes encoding agropine biosynthesis (ags) are also located on the $\mathrm{T}_{\mathrm{R}}$-DNA region (Willmitzer et al. 1982; Huffman et al. 1984; Lahners et al. 1984; Vilaine and Casse-Delbart 1987; Giri and 


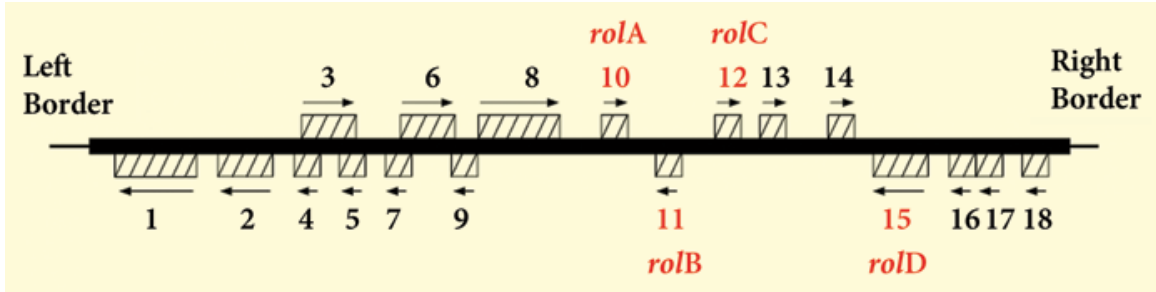

TL-DNA

Fig. 1.7 Schematic representation of gene locations on $T_{L}$-DNA

Narasu 2000; Christey 2001). Deletion of the right border of nopaline-type or octopine-type T-DNA in Ri plasmids appears to affect virulence. Also, mutations created within this region have the same effect as removing the tms loci of Ti plasmid resulted with being avirulent on plants. The deletion of $T_{L}$-DNA in Ri plasmids is being less susceptible to oncogenic transformation than the $T_{R}$-DNA deletion (Vilaine and Casse-Delbart 1987). Expression of the $T_{R}-D N A$ alone can induce root formation in some plants, but the resulting phenotype is not as strong as when both $\mathrm{T}_{\mathrm{L}}$ - and $\mathrm{T}_{\mathrm{R}}$-DNA are introduced together (Vilaine and Casse-Delbart 1987).

\section{T $_{\text {L }}$-DNA}

The size of $T_{L}$-DNA of agropine type Ri-plasmid is about 19-20 kb in length but, unlike the $\mathrm{T}_{\mathrm{R}}$-DNA, it does not appear to be closely related to any other characterized loci of Ti-plasmids (Huffman et al. 1984; Vilaine and Casse-Delbart 1987; Aoki and Syono 1999; Chandra 2012). In many species, T -DNA size seems almost constant, except in Nicotiana tabacum consisting shorter $\mathrm{T}_{\mathrm{L}}$-DNA (Jouanin et al. 1987b). The mannopine/cucumopine type T-DNAs and the agropine type $T_{L}$-DNA contain two strongly conserved regions which flank an only partially homologous central region (Filetici et al. 1987; Brevet and Tempe 1988; Aoki and Syono 1999; Chandra 2012). A substance carrying out stimulation of hairy root differentiation under the influence of endogenous auxin is synthesized by genes of $\mathrm{T}_{\mathrm{L}}$-DNA (Ooms et al. 1986; Shen et al. 1988; Giri and Narasu 2000; Mishra and Ranjan 2008).

As a result of mutagenesis in $\mathrm{T}_{\mathrm{L}}$-DNA of Ri plasmid, the loss or attenuation of virulence is shown (White et al. 1985). The $\mathrm{T}_{\mathrm{L}}$-DNA of Ri plasmids carrying several loci is identified to be essential for hairy root induction (so-called rol genes for root oncogenic loci) (Fig. 1.7). Transposon mutagenesis in the $T_{L}$-DNA has identified at least four genes (rolA, rolB, rolC and rolD) involved in tumorigenesis as affecting some plants (White et al. 1985; Estramareix et al. 1986; Slightom et al. 1986; Vilaine and Casse-Delbart 1987; Meyer et al. 2000; Christensen et al. 2008). All rol genes have been shown to carry out formation of hairy root phenotype (White et al. 1985; Cardarelli 1987a; Jouanin 1987a; Vilaine et al. 1987a; Schmulling et al. 1988; 
Petersen et al. 1989; Lee et al. 2001; Bensaddek et al. 2008). It has been reported that the $\mathrm{T}_{\mathrm{L}}$-DNA of the agropine-type Ri plasmid consists of at least 18 open reading frames (ORF). ORF 10, 11, 12 and 15 coincided with rolA, rolB, rolC and rolD, respectively (Slightom et al. 1986; Scorza et al. 1994).

\section{Rol Genes}

The T-DNAs have many other genes other than those opine and hormone synthesis genes. Although their functions are not well characterized, they are known to have very strong effects on growth. At least four genetic loci (rolA, B, C and D) were identified in the T-DNA regions of pRiA4 by a series of deletions and transposon insertions studies and shown to play important roles of root-inducing properties of $A$. rhizogenes on the $\mathrm{T}_{\mathrm{L}}$-DNA (Table 1.1) (White et al. 1985). The rol genes located on the $\mathrm{T}_{\mathrm{L}}$-DNA of Ri plasmid modify auxin and cytokinin biosynthesis and/ or endogenous hormone levels and their expressions stimulate the formation of roots in transformed tissues (Nilsson et al. 1993a; Maurel et al. 1994; Moritz and Schmülling 1998; Shen et al. 1990; Bonhomme et al. 2000; Ishizaki et al. 2002; Hong et al. 2006; Bensaddek et al. 2008). Studies have focused on characterizing the three rol genes named as rolA, rolB, and rolC because they are considered essential for the hairy root initiation based on transposon "loss-of-function" analysis (White et al. 1985). Induced adventitious root formation by rolA, rolB and rolC genes is shown on tobacco, kalanchoe and tomato leaves (Cardarelli et al. 1987a; Spena et al. 1987; Vilaine et al. 1987; Spano et al. 1988; van Altvorst et al. 1992; Kiyokawa et al. 1994) and plants carrying these genes are morphologically equivalent to those carrying the whole $\mathrm{T}_{\mathrm{L}}$-DNA (Spano et al. 1988). Inactivation or overexpression of various rol genes in stable transgenic lines or hairy-root cultures exhibits different variations in plant phenotypes and root morphology (Schmulling et al. 1988; Martin-Tanguy et al. 1996; Casanova et al. 2004).

\section{rolA}

The rolA gene is found on all Ri plasmids and encodes a small protein with a molecular mass of approximately $11 \mathrm{kDa}$ (Nilsson and Olsson 1997). The rolA gene sequence length differs in various $A$. rhizogenes strains ranges from 279 to $423 \mathrm{bp}$ (Meyer et al. 2000). Analysis of amino acid sequences showed that rolA encodes a protein with basic isoelectric point (PI 11.2). It also contains a frequent sequence motif common in DNA-binding proteins (Suzuki 1989) and proposed to function as a regulatory transcription factor (Levesque et al. 1988; Veena and Taylor 2007).

A dramatic reduction in several classes of hormones, including auxin, cytokinin, gibberellic acid (GA) and abscisic acid triggered by the expression of rolA gene is 
Table 1.1 Oncogenes of $A$. rhizogenes, their encoded proteins, functions and phenotypic changes in host plants

\begin{tabular}{|c|c|c|c|}
\hline Gene & Protein & Function & Phenotype \\
\hline rolA & $\begin{array}{l}\text { Sequence motif } \\
\text { common in DNA- } \\
\text { binding proteins } \\
\text { Regulatory transcrip- } \\
\text { tion factor }\end{array}$ & $\begin{array}{l}\text { Inhibits cell elongation via } \\
\text { diffusible factor } \\
\text { Decreases hormone } \\
\text { concentrations } \\
\text { Increase sensitivity to auxin } \\
\text { Modulating hormone physiol- } \\
\text { ogy of GA } \\
\text { Interfere polyamine } \\
\text { metabolism } \\
\text { Correlate with plasma mem- } \\
\text { brane } \mathrm{H}^{+} \text {ATPase activity }\end{array}$ & $\begin{array}{l}\text { Stunted growth, dark green } \\
\text { wrinkled leaves with } \\
\text { an altered length to } \\
\text { width ratio, condensed } \\
\text { inflorescences, retarded } \\
\text { onset of flowering, } \\
\text { compact reduced number } \\
\text { of flowers }\end{array}$ \\
\hline rolB & $\begin{array}{l}\text { Localizes to plasma } \\
\text { membrane }\end{array}$ & $\begin{array}{l}\text { Alterations in the reception/ } \\
\text { transduction of the auxin } \\
\text { signal } \\
\text { Stimulates new meristem } \\
\text { formation } \\
\text { Induce secondary metabolism }\end{array}$ & $\begin{array}{l}\text { Fast growth, root meri- } \\
\text { stem neoformation, } \\
\text { high branching and } \\
\text { plagiotropism }\end{array}$ \\
\hline rolc & $\begin{array}{l}\text { Phloem-specific } \\
\text { expression in the } \\
\text { root, low expres- } \\
\text { sion in the leaf, } \\
\text { and no expression } \\
\text { in the shoot tip }\end{array}$ & $\begin{array}{l}\text { Reduces cell size } \\
\text { Reduces abscisic acid (ABA), } \\
\text { polyamine, and ethylene } \\
\text { levels } \\
\text { Formation of shoot meristems } \\
\text { Regulate sugar metabolism } \\
\text { and transport } \\
\text { Stimulate the production of } \\
\text { high levels of secondary } \\
\text { metabolites }\end{array}$ & $\begin{array}{l}\text { Increased branching, } \\
\text { dwarfed plants with short } \\
\text { internodes, reduced epi- } \\
\text { dermal cell size in inter- } \\
\text { nodes, lanceolate leaves, } \\
\text { early flowering, reduced } \\
\text { flower size and reduced } \\
\text { pollen production }\end{array}$ \\
\hline rolD & $\begin{array}{l}\text { Only expresses in } \\
\text { Agropine type } \\
\text { strains } \\
\text { Cytosolic protein } \\
\text { Exhibits poor tissue- } \\
\quad \text { or organ-specific } \\
\text { expression }\end{array}$ & $\begin{array}{l}\text { Incapable of inducing root } \\
\text { formation on its own } \\
\text { Provide defense response as } \\
\text { a result of environmental } \\
\text { stress }\end{array}$ & $\begin{array}{l}\text { Increased flowering, reduced } \\
\text { rooting, elongating and } \\
\text { expanding tissues of each } \\
\text { organ but not on apical } \\
\text { meristem, callus growth } \\
\text { giving rise to initia- } \\
\text { tion of tumor resemble } \\
\text { formation }\end{array}$ \\
\hline$r o l \mathrm{~B}^{\mathrm{TR}}$ & $\begin{array}{l}\text { CX5R motif is absent } \\
\text { N-terminal part } \\
\text { contain } 14 \text { amino } \\
\text { acids }\end{array}$ & $\begin{array}{l}\text { rolB homolog on TR-DNA } \\
\text { in the agropine type Ri } \\
\text { plasmid }\end{array}$ & $\begin{array}{l}\text { Wrinkled leaves bent } \\
\text { strongly downward, } \\
\text { formed shoots at the base } \\
\text { of the stem and retarded } \\
\text { growth }\end{array}$ \\
\hline ORF3n & $\begin{array}{l}\text { Modification of phe- } \\
\text { nolic enzymes and } \\
\text { involve secondary } \\
\text { metabolism and/ } \\
\text { or the transport of } \\
\text { hormones }\end{array}$ & $\begin{array}{l}\text { Negative regulator to the } \\
\text { dedifferentiation of tissues }\end{array}$ & $\begin{array}{l}\text { Retarded flowering, less } \\
\text { dense inflorescences, } \\
\text { altered internode elonga- } \\
\text { tion and leaf morphology } \\
\text { and necrotic tips of upper } \\
\text { leaves, sepals and bracts } \\
\text { no sign of necrosis on the } \\
\text { basal leaves }\end{array}$ \\
\hline
\end{tabular}


Table 1.1 (continued)

\begin{tabular}{|c|c|c|c|}
\hline Gene & Protein & Function & Phenotype \\
\hline ORF8 & $\begin{array}{l}\text { Fusion protein } \\
\text { consisting of } \\
\text { N-terminal } \\
\text { domain (NORF8) } \\
\text { and C-terminal } \\
\text { part (CORF8) } \\
\text { Tryptophan monoox- } \\
\text { ygenase activity }\end{array}$ & $\begin{array}{l}\text { Modifies sucrose transport } \\
\text { N-terminal domain causes } \\
\text { sugar/starch accumulation } \\
\text { C-terminal domain reduces } \\
\text { sugar/starch accumulation }\end{array}$ & $\begin{array}{l}\text { Growth retardation, chlo- } \\
\text { rotic and necrotic leaves } \\
\text { and accumulation of high } \\
\text { levels of sugars (glucose, } \\
\text { fructose and sucrose) and } \\
\text { starch }\end{array}$ \\
\hline ORF13 & $\begin{array}{l}\text { Contains a con- } \\
\text { servative } \\
\text { retinoblastoma } \\
\text { (RB)-binding } \\
\text { motif LxCxE }\end{array}$ & $\begin{array}{l}\text { Hormone homeostasis and } \\
\text { regulation of the cell cycle } \\
\text { Increases number of mitoses } \\
\text { in shoot apical meristem } \\
\text { Induces dedifferentiation (pre- } \\
\text { requisite to competence) } \\
\text { Graft transmissible }\end{array}$ & $\begin{array}{l}\text { Induce cell proliferation } \\
\text { such as dense green and } \\
\text { rapidly proliferating cal- } \\
\text { lus, including irregular } \\
\text { formation of leaves, } \\
\text { severe leaf nervure, } \\
\text { shortened and variable } \\
\text { internode length, abnor- } \\
\text { mal and asymmetric } \\
\text { flowers, agravitropic root } \\
\text { growth and a reduced } \\
\text { cell number and cell size } \\
\text { in the root }\end{array}$ \\
\hline ORF13a & $\begin{array}{l}\text { Tissue specific } \\
\text { manner in plants, } \\
\text { primarily in leaf } \\
\text { vascular tissues } \\
\text { May interact directly } \\
\text { with DNA } \\
\text { SPXX repeat motif }\end{array}$ & $\begin{array}{l}\text { Necessary for root induction } \\
\text { Regulatory function of itself }\end{array}$ & $\begin{array}{l}\text { Not yield a visible } \\
\text { phenotype }\end{array}$ \\
\hline ORF14 & Auxin like effect & $\begin{array}{l}\text { Act together with ORF13 to } \\
\text { induce root induction }\end{array}$ & No morphological change \\
\hline
\end{tabular}

observed in $N$. tabacum. The reduction ratio depends on tissue type and growth stage of the plant (Dehio et al. 1993). It was demonstrated that despite low level of auxin concentration, auxin sensitivity is enhanced in transgenic plants (Maurel et al. 1991; Vansuyt et al. 1992). Additionally, the effects of rolA can be attenuated, probably through methylation (Martin-Tanguy et al. 1996; Lee et al. 2001). Inactivation of rolA leads to the formation of long, straight roots giving a less compact appearance on Kalanchoe daigremontiana leaves (Vilaine and Casse-Delbart 1987). Transgenic $N$. tabacum plants are also show stunted growth, dark green wrinkled leaves with an altered length to width ratio, condensed inflorescences, retarded onset of flowering, a reduced number of flowers and compact styles (Dehio et al. 1993).

A. rhizogenes infected plant tissues are 100 times more sensitive to auxin than normal phenotype exhibiting plant tissues. This suggests that the increased sensitivity of transformed plants should not be due to a particular insertion position of the rolA gene in the transgenic plant genome, but rather reflects the effect(s) of the rolA gene product (Vansuyt et al. 1992). It was found that $N$. tabacum leaves of rolA 
transgenic clones show $40-60 \%$ reduction of GA content compared to wild-type leaves. The reduction of GA content is indirectly cause stem elongation and planar leaf blade growth (Dehio et al. 1993). When the wild-types of N. tabacum treated by gibberellin biosynthesis inhibitors, rolA expressing plants and wild types show similar phenotypes. On the other hand, when rolA transgenic plants treated with GA, the phenotype of transgenic plant not completely restored (Dehio and Schell 1993; Dehio et al. 1993). All these shows that the rolA gene has been considered in playing an important role in modulating hormone physiology of GA and polyamine metabolism (Sun et al. 1991; Dehio and Schell 1993; Dehio et al. 1993; Prinsen et al. 1994; Martin-Tanguy et al. 1996; Veena and Taylor 2007). It was thought that the sensitivity of auxin response might correlate with plasma membrane $\mathrm{H}^{+}$ATPase activity observed in rolA expressing transgenic plants (Maurel et al. 1991; Vansuyt et al. 1992).

There is data suggesting that there is an antagonism between $r o l \mathrm{~A}$ and $\mathrm{rol \textrm {B }}$ genes in general. An observation of additional transcripts ranging from 2.1 to $2.8 \mathrm{~kb}$ in size explains this antagonism (Durand-Tardif et al. 1985). Size of transcription of rolA would be more than $2 \mathrm{~kb}$. This would span the whole rolB sequence, leading to the generation of an antisense message for rolB. Its occurrence could be the major cause of antagonism between rolA and $r o l \mathrm{~B}$ in the transformed plant cells. Probably, existence of a mechanism prevents co-expression of rolA and rolB (Capone et al. 1989; van Altvorst et al. 1992; Veena and Taylor 2007).

\section{rolB}

The rolB gene size ranging 765 (strain 8196) to $840 \mathrm{bp}$ (strain 2659) length depending on the strain and encodes 254-279 amino acid protein which has molecular weight of $30 \mathrm{kDa}$ localized in the plasma membrane (Filippini et al. 1996; Meyer et al. 2000; Veena and Taylor 2007). rolB gene is present in all Ri plasmids with approximately $60 \%$ identity between strains (Meyer et al. 2000). RolB proteins encoded by pRi1724 and pRi2659 have a 17 amino acid longer N-terminal stretch than the RolB proteins encoded by pRi1855 (pRiA4) (Meyer et al. 2000). The physical presence of the rolB gene in $\mathrm{T}_{\mathrm{L}}$-DNA segment of Ri plasmid of the infecting Agrobacterium in leaf tissues of plants regenerated from selected rhizoclones was demonstrated by a positive PCR amplification (Pal et al. 2012).

The reports have shown that the RolB may have a critical role in early steps of hairy-root induction (Bellincampi et al. 1996). The root induction is totally alleviated when rolB gene is inactivated in the pRiA4 on kalanchoe leaves (White et al. 1985). rolB also has capacity nearly as much as the wild type A. rhizogenes TDNA for enhancing rooting and hairy root formation on wounded $N$. tabacum stems (Cardarelli et al. 1987b; Bellincampi et al. 1996; Altamura and Tomassi 1998; Binns and Costantino 1998) and leaves (Spena et al. 1987).

Phenotypical abnormalities such as root meristem neoformation on leaf discs and fast growth of rolB-transgenic plants and growth pattern of rolB-induced roots are characterized by fast growth, high branching, and plagiotropism. As a result of these 
observations firstly suggested that there is a similarity between the auxin-mediated effects and morphogenic effects of rolB. However, further studies demonstrated that an auxin-induced hyperpolarization at the plasma membrane is exhibited by rolB-transformed plants. The morphogenic effects of $r o l \mathrm{~B}$ involve changes in either the responsiveness to auxin or in auxin content (Cardarelli et al. 1987b; Shen et al. 1988; Capone et al. 1989; Maurel et al. 1991). Activation of auxin-induced hyperpolarization through $\mathrm{H}^{+}$ATPase protein pump at the plasma membrane appears to be related to the proton excretion (Ephritikhine et al. 1987; Keller and Van Volkenburgh 1998). rolB gene causes transformed plant cells to bind more auxin than wild type and the additional auxin-binding activity is completely abolished by using antiRolB antibodies (Filippini et al. 1994; Shoja 2010).

Estruch et al. (1991) reported that RolB protein exhibits a $\beta$-glucosidase activity able to hydrolyze biologically active indole-3-glucosidese. It can be explained by the increased auxin perception and sensitivity with releasing the hormone from $\beta$-glucoside conjugates. As a result of increase concentration of auxin cause the phenotypic alterations observed in rolB transgenic tissues (Shen et al. 1988, 1990; Maurel et al. 1991, 1994; Meyer et al. 2000). However, later studies showed that neither the intracellular concentration nor the metabolism of auxin was changed by $r o l \mathrm{~B}$ expression in plant cells. Rather, the increased auxin sensitivity of rolBtransformed cells results from alterations in the reception/transduction of the auxin signal (Nilsson et al. 1993b; Schmülling et al. 1993; Delbarre et al. 1994; Bellincampi et al. 1996; Veena and Taylor 2007).

Overexpressing rolB gene under a constitutive promoter in transgenic plants suppresses adventitious root induction (Spena et al. 1987) and necrosis in callus tissues and leaves of young plants (Schmulling et al. 1988). Both callus and root formations at wound sites are cancelled if mutations occur in rolB gene (Vilaine and Casse-Delbart 1987). Normal growth of these organs depends upon the expression level of rolB gene necessary for active growth of hairy roots. A high or low level of expression correlates with impaired growth of these organs (Tanaka et al. 2001; Veena and Taylor 2007).

$A$. rhizogenes rol genes enhance the biosynthesis of certain groups of secondary metabolites in transformed plant cells. It was shown that rolB is apparently the most powerful inducer of secondary metabolism and at the same time, the most important inhibitor of callus growth (Palazon et al. 1998; Bonhomme et al. 2000; Bulgakov et al. 2002a; Shkryl et al. 2008; Shoja 2010). rolB gene mediated stimulatory effect on resveratrol and anthraquinone production suppresses with the tyrosine phosphatase inhibitors proven that RolB also has tyrosine phosphatase activity (Filippini et al. 1996; Kiselev et al. 2007).

\section{rolC}

The rolC gene sequences vary in different strains but their sizes are similar and ranging between 537 bp (strain 8196) to 543 bp (strain 2659, 1724 and A4). rolC 
gene encodes 178-180 amino acid protein (approximately $20 \mathrm{kDa}$ ) that share more than $65 \%$ identity with each other (Meyer et al. 2000).

rolC transformed plants exhibited reduced apical dominance leading to increased branching, dwarfed plants with short internodes, lanceolate leaves, early flowering, reduced flower size and reduced pollen production (Schmulling et al. 1988). Dwarfing was caused by reduced epidermal cell size in internodes (Oono et al. 1990). Regulation of expression of rolC is complex, and varies depending upon the existence of the complete T-DNA sequences. In addition, root production was increased compared to untransformed plants, but decreased compared to plants transformed with the complete set of rol genes (Palazòn et al. 1998). Expressing rolC shows phloem-specific expression in the root, low expression in the leaf, and no expression in the shoot tip (Schmulling et al. 1988; Estruch et al. 1991). However, rolC is highly expressed in leaves when the whole T-DNA is present (Durand-Tardif et al. 1985; Leach and Aoyagi 1991). More recently, rolC gene has been shown to play a role in formation of shoot meristems, hence suggesting its important role in the formation of pluripotent stem cells (Gorpenchenko et al. 2006).

The $r o l \mathrm{C}$ promoter is utilized extensively for phloem-specific gene expression making it a useful tool in some biotechnological programs on pathogen resistance. Replication of many plant viruses, including luteoviruses, reoviruses and most geminiviruses transmitted by hemipteran vectors occur exclusively in phloemassociated tissues. Therefore, by introducing an insecticidal gene that is toxic to hemipteran vectors under the control of phloem-specific rolC is a promising way for the control of such viruses through its expression in transgenic plants (Graham et al. 1997). Similarly, a plant lectin with insecticidal activity is encoded by $\overline{A S A L}$ (Allium sativum leaf agglutinin) gene and under control of the rolC promoter, it confers resistance against various hemipteran pests in transgenic rice, tobacco and chickpea plants (Saha et al. 2007).

$\mathrm{rolC}$ is known to stimulate rooting by an auxin-like effect of the gene (Schmulling et al. 1988; Zuker et al. 2001; Casanova et al. 2003). An increase in auxin sensitivity may lead to occurrence of the auxin-like effect. In fact, in comparison between rolC transgenic $N$. tabacum protoplasts and their wild-type counterparts showed that more sensitivity was recorded in transgenic $N$. tabacum in the measurement of transmembrane hyperpolarization in response to auxin (Maurel et al. 1991; Shoja 2010).

Also, abscisic acid (ABA), polyamine, and ethylene levels are extensively reduced due to $\mathrm{rol} \mathrm{C}$ expression. The promoter of rolC activated by sucrose was found to be very high (Yokoyama et al. 1994; Faiss et al. 1996), implying that rolC may be influencing the source-sink relationship of a plant by regulating sugar metabolism and transport (Nilsson et al. 1996a, b; Martin-Tanguy 2001).

Alike $r o l \mathrm{~B}$, the $r o l \mathrm{C}$ gene is able to stimulate the production of high levels of secondary metabolites such as tropane alkaloids (Bonhomme et al. 2000), pyridine alkaloids, indole alkaloids (Palazon et al. 1998), ginsenosides (Bulgakov et al. 1998) and anthraquinone phytoalexins (Bulgakov et al. 2002b; Shkryl et al. 2008; Shoja 2010) in transgenic plants. 


\section{rolD}

The rolD gene is found only in $\mathrm{T}_{\mathrm{L}}$-DNA of agropine type Ri plasmids. It is also the only rol gene that is incapable of inducing root formation on its own (Mauro et al. 1996). The rolD gene size 1,032 bp and encodes a protein of 344 amino acids (Meyer et al. 2000; Christey 2001). This is a cytosolic protein with a sequence similar to ornithine cyclodeaminase (OCD) that catalyzes the conversion of ornithine to proline. Proline is an osmoprotectant and its accumulation is considered to be a defense response as a result of environmental stress in many plant species (Mauro et al. 1996; Trovato et al. 2001; Bettini et al. 2003). High levels of proline accumulation are in flowers suggesting a role in flowering (Trovato et al. 2001). The pleiotropic effects induced by expression of rolD gene in transgenic plants are increased flowering and reduced rooting (Mauro et al. 1996; Trovato et al. 2001). Although flower yield is accelerated, the flowers show heteromorphic incompability, which prevents self-fertilization. Production of viable seeds is achieved through manually-selfed plants (Mauro et al. 1996). However, it should be noted that these experiments were conducted using the rolD sequence from pRi1855. It has been reported that the induction of flowering is not performed by rolD from pRiHRI (Lemcke and Schmulling 1998). rolD exhibits poor tissue- or organ-specific expression in comparison with other rol genes but is shown to have a predominantly developmental expression pattern (Vilaine and Casse-Delbart 1987). Activity is seen in the elongating and expanding tissues of each organ in adult plants, but never in apical meristems. As the plants age, expression decreases and ceases at senescence. The mutations in rolD appear to accentuate callus growth giving rise to initiation of tumor formation resembling the Ti-plasmid infection (Trovato et al. 1997).

\section{rolB ${ }^{\mathrm{TR}}$ (rolB Homologue in $T_{R}-\mathrm{DNA}$ )}

A rolB homolog on $\mathrm{T}_{\mathrm{R}}$-DNA in the agropine type Ri plasmid was discovered and named as rolB $\mathrm{B}^{\mathrm{TR}}$. Excluding the $5^{\prime}$ or $3^{\prime}$ flanking sequences, there is a $53 \%$ nucleotide similarity between $r o l \mathrm{~B}^{\mathrm{TR}}$ and $r o l \mathrm{~B}$ in their sequences (Bouchez and Camilleri 1990). The expression of rol $\mathrm{B}^{\mathrm{TR}}$ in $N$. tabacum is shown to cause phenotypical alterations such as wrinkled leaves bent strongly downward, formed shoots at the base of the stem and retarded growth is observed which are different than rolB phenotype. Two big differences were noted by the alignment of protein sequences of $r o l \mathrm{~B}$ and $r o l \mathrm{~B}^{\mathrm{TR}}$. First, a CX5R motif is absent in $r o l \mathrm{~B}^{\mathrm{TR}}$ and second, $\mathrm{N}$-terminal part of RolB ${ }^{\mathrm{TR}}$ contains 14 amino acids and mutations in the corresponding sequence in rol $\mathrm{B}^{\mathrm{TR}}$ gene cause abolishment of the altered phenotype (Lemcke and Schmulling 1998). 


\section{ORF Genes}

Besides rol (root locus) genes, there are several ORFs (Open Reading Frames) located on the $T_{L}$-DNA (Slightom et al. 1986). Many of 18 open reading frames (ORFs) nucleotide sequences identified on $\mathrm{T}_{\mathrm{L}}$-DNA region contain $5^{\prime}$ and $3^{\prime}$ regulatory elements similar to those found in eukaryotic genes. They have at least 255 nucleotides and start with the initiation codon ATG (Slightom et al. 1986; Holefors et al. 1998). In many cases, CCAAT and TATA elements were situated upstream of putative transcriptional initiation codons and poly(A) addition (AATAAA) elements were present in presumed 3'-noncoding regions (Slightom et al. 1986). The sequence length of coding regions of ORFs differ in ranging from $255 \mathrm{bp}$ (ORF 9) up to $2280 \mathrm{bp}$ (ORF8) and encode protein products ranging in size from 9,600 to 85,000 daltons, respectively. The results from analysis of insertion mutants within the T-DNA region (White et al. 1985) and transformation experiments with individual or combinations of the ORFs have showed that the open reading frames ORF10, 11 and 12, corresponding to the genes $r o l \mathrm{~A}, r o l \mathrm{~B}$ and $r o l \mathrm{C}$, were able to promote the formation of hairy root syndrome (Table 1.1) (Jouanin et al. 1987b; Vilaine et al. 1987; Spena et al. 1987; Spano et al. 1988; Schmulling et al. 1988). Besides this, it has been showed that ORF3n, ORF8 and ORF13 DNA sequences are highly conserved among all known Ri plasmids, indicating that they alter plant morphogenesis or response of transgenic tissues to plant hormones (Lemcke and Schmulling 1998; Veena and Taylor 2007). The sensitivity to auxin and cytokinin in combination or auxin alone can be lowered by expressions of both ORF3n and ORF8 (Lemcke and Schmulling 1998).

\section{ORF3n}

Expression of ORF3n in transgenic N. tabacum caused retarded flowering, less dense inflorescences, altered internode elongation and leaf morphology and necrotic tips of upper leaves, sepals and bracts (Lemcke and Schmulling 1998). Appearance of localized necrosis was noticed on the tips of apical narrow leaves whereas there was no sign of necrosis on the basal leaves. Additionally, senescence was not altered in these leaves, and bracts became necrotic as a whole. On sepals, the necrosis emerged on the tips just when the corolla was visible through the calyx (Koltunow et al. 2001; Lemcke and Schmulling 1998). The ORF3n protein (48.7 kDa) resembles phenolic-modifying enzymes and may be involved in secondary metabolism and/or the transport of hormones (Binns et al. 1987; Jacobs and Rubery 1988; Lemcke and Schmulling 1998). A cessation was observed in the shoot formation from ORF3n callus in response to auxin and cytokinin. Also, plantlets transferred to the medium containing auxin and cytokinin showed decreased sensitivity leading to small and fewer calli than controls. Thus, it has been proposed that ORF3n may act to negative regulator to the dedifferentiation of tissues as a reaction to auxin and cytokinin, which may favor the formation of rol gene-induced roots from such cells during pathogenesis (Britton et al. 2008; Dodueva 2007). 


\section{ORF8}

The ORF8 gene has the longest sequence of $\mathrm{T}_{\mathrm{L}}$-DNA and coding for a protein containing 780 amino acids (Slightom et al. 1986). The ORF8 protein has one of the most conserved amino acid sequences ( $81 \%$ similarity) between different strains like pRiA4 and pRi2659 (Ouartsi et al. 2004).

The protein encoded by the ORF8 gene is a natural fusion protein consisting of N-terminal domain (NORF8) of 213 amino acids homologous to RolB protein of the $A$. rhizogenes strain A4 T-DNA and the C-terminal part (CORF8) of approximately 506-524 amino acids shows homology to the IaaM proteins of various other bacteria (Yamada et al. 1985; Slightom et al. 1986; Levesque et al. 1988; Dodueva 2007; Shoja 2010). iaaM genes that homologues to the coding sequence of CORF8 codes for a tryptophan monooxygenase which catalyzes the formation of indole-3acetamide (IAM) from tryptophan (Lemcke et al. 2000).

Furthermore, ORF8 possesses a 200 amino acid stretch at its N-terminus that shows homology with the rolB gene product (33.5\% amino acid identity) (Levesque et al. 1988). The N-terminal part (NORF8) of this protein functions in carbohydrate metabolism such that when only NORF8 was expressed, transformed plant showed growth retardation, chlorotic and necrotic leaves and accumulation of high levels of sugars (glucose, fructose and sucrose) and starch (Otten and Helfer 2001).

However, some studies show that the auxin content can be elevated by the genes found in the $T_{L}$-DNA region on the T-DNA in some hosts, independent of the presence of the $T_{R}$-DNA (Lemcke et al. 2000). Presumably this occurs because of conversion of IAM to IAA in cells expressing only t2m protein (Klee et al. 1987; Prinsen et al. 1990). Besides this, as a characteristic functional motif of the $t 2 \mathrm{~m}$ proteins that catalyzes decarboxylation of tryptophan to indole-3-acetamide exhibits 23-aminoacid- long a flavin adenine dinucleotide (FAD) binding site was identified by Levesque et al. (1988). The experimental data obtained from plants and bacteria suggest that the gene product of ORF8 of $A$. rhizogenes $\mathrm{T}_{\mathrm{L}}$-DNA has $\mathrm{t} 2 \mathrm{~m}$ activity responsible for the increased IAM content in transgenic tissues (Lemcke et al. 2000). Moreover, there is a physical connection between $\mathrm{N}$ - and C-regions of ORF8 protein required for the emergence of a specific phenotype in transgenic plants consisting ORF8 gene. This suggests a distinct specific function for the whole protein (Umber et al. 2005; Dodueva 2007).

\section{ORF13 and ORF14}

The ORF13 and ORF14 genes are found to be highly conserved among A. rhizogenes strains (Stieger et al. 2004). It has been demonstrated that alone A4-rolABC genes carried by an Agrobacterium strain are showed to be incapable of inducing rooting on carrot disc and aux genes located on the $\mathrm{T}_{\mathrm{R}}$-DNA or ORF13 and ORF14 located on $\mathrm{T}_{\mathrm{L}}$-DNA are also required for rooting (Cardarelli et al. 1987b; Capone 
et al. 1989). In N. tabacum leaf discs harboring rolB and ORF13 genes had capacity to induce rooting almost as well as the full length of $\mathrm{T}_{\mathrm{L}}$-DNA (Aoki and Syono 1999). The results obtained via co-inoculation of leaf discs achieved using the rolA, $\overline{r o l \mathrm{~B}}$ and rolC with either ORF13 or ORF14 showed a limited root induction on carrot disks (Capone et al. 1989). A comparison from the studies showed that there is no homology between ORF13/ORF14 and auxin biosynthetic genes. Furthermore, unlike the genes controlling biosynthesis of auxin (Camilleri and Jouanin 1991), ORF13 and ORF14 have no activity for the induction of roots on $N$. tabacum leaf discs (Cardarelli et al. 1987b). A highly divergent gene family known as plast gene family is constituted by $r_{0} \mathrm{~B}$, rolC, ORF13 and ORF14. They have similar functions and are thought to be evolutionary related (Levesque et al. 1988).

The ORF13 gene is approximately $600 \mathrm{bp}$ in size, encoding a 197-200 amino acid protein, whose expression leads to higher levels in leaves and roots (DurandTardif et al. 1985; Veena and Taylor 2007). ORF13 gene leads to the formation of induce cell proliferation such as dense green and rapidly proliferating callus on transformed carrot root and tobacco leaf discs (Capone et al. 1989; Frundt et al. 1998; Dodueva 2007). Wound-inducible and organ-specific expression of ORF13 in transgenic plants lead to a variety of characteristic modifications including irregular formation of leaves, severe leaf nervure, shortened and variable internode length, abnormal and asymmetric flowers, agravitropic root growth and a reduced cell number and cell size in the root (Hansen et al. 1993, 1997; Lemcke and Schmulling 1998; Veena and Taylor 2007). Accelerated expression level in ORF13 gene triggered a more severe reduction of growth in stem and roots through TC-dependent overproduction of the ORF13 gene product, affecting both cell number and cell size in the root. Interestingly, growth and gravitropism was normal in the ORF13 high expressers (Lemcke and Schmulling 1998).

Expression of ORF13 provokes specific phenotype similar to cytokinin-treated plants however free or bound cytokinin content of the transformed tissues shows no difference from wild-type (Medford et al. 1989; Hansen et al. 1993; Lemcke and Schmulling 1998). Furthermore, the shoot part of the ORF13 transformed plant does not resemble cytokinin-overproducing plants, indeed the growth reduction results from the inhibition of cell division in the apical meristems and development of leaves (Lemcke and Schmülling 1998). Some of the phenotypic alterations in transgenic plants are thought to arise from interaction of ORF13 with hormone signaling pathways. ORF13 may play roles in hormone homeostasis and regulation of the cell cycle in infected cells (Veena and Taylor 2007). The observations and grafting of transgenic shoots onto wild type plants revealed that ORF13 may cause the production of a diffusible factor with cytokinin-like activity (Hansen et al. 1993; Dodueva 2007).

Since the only T-DNA gene that induces cell proliferation is ORF13, when inoculated with both carrot discs and tobacco leaf discs produce green callus (Hansen et al. 1993; Frundt et al. 1998). Application of exogenous cytokinin increases the number of roots produced from ORF13 tobacco leaf discs, but does not change root induction on untransformed, even though there was no difference in endogenous cytokinin levels (Specq et al. 1994; Lemcke and Schmulling 1998, Britton et al. 2008). 
Furthermore, endoreduplication was reduced in ORF13 plants (Meyer et al. 2000), indicating an interaction of ORF13 with cell cycle control. Stieger et al. (2004) claimed that a proliferative effect of ORF13 expression in the shoot apical meristem (SAM) caused increased number of mitoses and showed no influence on meristem structure. In consequence, the reductions of cell and meristem sizes and the retardation in the formation of leaf primordia were observed. Smaller leaf sizes can be explained by an earlier cessation of leaf growth, but not explained with a reduced size of leaf cells, since the number of epidermal leaf cells per square millimeter was remain unaltered. Enhanced number of cell divisions in the shoot apical meristems and accelerated production of leaf primordia were seen in plant expressing ORF13. ORF13 is involved in the inference of the cell cycle regulation leading to an earlier stop in organ growth in the developing leaves. Furthermore, earlier flowering of plants expressing ORF13 may arrest leaf initiation and leaf expansion, explaining the fewer leaves formed in ORF13 plants (Stieger et al. 2004).

It has been also revealed that ORF13 protein contains a conservative retinoblastoma (RB)-binding motif LxCxE (Meyer et al. 2000). This motif was found in all members of the ORF13 family, including agropine-, mannopine-, cucumopine-, and mikimopine-type Ri plasmids (Stieger et al. 2004). When mutations are introduced into the $\mathrm{Rb}$ motif, normal leaf size is restored, but plants still show stunting and reduced apical dominance. It was also observed that ORF13 expression leads to the formation of spur between minor veins on leaves and petals N. tabacum (Meyer et al. 2000). Similar structures are formed on leaves, when KNOX (KNOTTED1like homeobox) genes are overexpressed (Sinha et al. 1993; Chuck et al. 1996; Sentoku et al. 2000; Stieger et al. 2004). It was explained that cytokinin-like phenotype such as the formation of spikes, stunted growth, loss of apical dominance, fusion of organs, and stem fasciations observed as consequences of ectopic expression of $K N O X$ genes which are induced by ORF1 and cell cycle regulations (Stieger et al. 2004).

Among the additional ORFs in the $\mathrm{T}_{\mathrm{L}}$-DNA, there are two genes, which may also contribute to the hairy root phenotype, ORF13a and ORF14. ORF13a is located between ORF13 and ORF14 on the opposite strand. Expression of this gene is taken place in a tissue specific manner in plants, primarily in leaf vascular tissues (Hansen et al. 1994b). ORF13a is necessary for root induction (Capone et al. 1989). ORF13a containing motifs common to phorphorylated gene regulatory proteins codes for a protein that may interact directly with DNA (Hansen et al. 1994b). Despite a higher expression rate of ORF13a was found in roots compared to leaves, its expression did not yield a visible phenotype (Lemcke and Schmulling 1998; Veena and Taylor 2007). The putative protein encoded by ORF13a has a SPXX repeat motif and is considered to have a regulatory function for this gene (Hansen et al. 1994b). ORF14 is in the same gene family as rolB, rolC, ORF8 and ORF13 (Levesque et al. 1988). Although overexpression of ORF14 in transgenic carrot and tobacco produced no morphological changes (Lemcke and Schmulling 1998), it has been shown that the rol genes and ORF13 act together to induce root induction (Capone et al. 1989; Aoki and Syono 1999) (Table 1.1). 


\section{A. rhizogenes and Crop Biotechnology}

Genes can be transferred between species and in conjunction with this fact; plant improvements for many decades have been relied heavily upon gene transfer. Either by natural selection or through the efforts of plant breeders, development of plants has always depended upon creating, evaluating and selecting of right combination of alleles. Transgenic plants possessing useful features such as resistance to diseases, insects and pests have been developed by transferring such traits to crop varieties from different species.

Since 1970, rapid progress being made in developing tools for recombinant DNA technology has led to the creation of genetically modified plants. Genetically modified crops have been developed for improving various agricultural, nutritional and food processing traits and used commercially all over the world (Miflin 2000; Kuiper et al. 2001; James 2006; Olempska-Beer et al. 2006). Establishment of plant tissue culture techniques are the most important and preliminary steps for many direct (electroporation, biolistic, microinjection, etc.) and indirect (virus- or bacteria-mediated) gene transfer methods in biotechnology and these methods are used successfully by a lot of laboratories around the world (Ozyigit 2012). The particle bombardment and electroporation transformation methods were favored DNA delivery systems because they do not show any plant host range problems and very effective with high DNA delivery rate (Hauptmann et al. 1987; Birch 1997; Taylor and Fauquet 2002; Turgut-Kara and Ari 2010). However with these methods, gene silencing/co-suppression can be occurred as a result of high copy number of DNA inserted in host cells (Block 1993; Yasuda et al. 2005). On the other hand, Agrobacterium-based plant transformation is very effective method of creating plants at low cost, simple to use and with low copy number inserted. Limited number of host range is the only disadvantage (Lessard et al. 2002; Chandra 2012). For achieving transformation of plants, Agrobacterium based technology has been used since the mid-1990s increasingly (Hiei et al. 1994). Agrobacterium-mediated transformation in generating transgenic plants has been employed as a major DNA delivery system for novel transgenic technologies starting with the transformations of dicotyledonous (Zambryski et al. 1983) and monocotyledonous (Hiei et al. 1994) species in the 1980-1990s. Increasing understanding of Agrobacterium-plant relationship (Gelvin 2003) and the mechanisms of transgene integration and genetic recombination in plants (Vain 2007) will lead to achieve further advances in these areas. Conducting efficient and controlled research on targeted gene replacement/alteration, overexpression and mis-expression could provide valuable resource to define gene regulation/function and traits in further in crops. Achievements on Agrobacterium-based transformation technologies enable large-scale transgenic studies in a range of important plant and crop species (such as indica rice, wheat, barley, etc.) (Vain 2007) and also bring opportunity to define and select plant cultivars, which could not be obtained by conventional breeding methods (Christou 1997).

For many crops, aim of breeding program is altering plant forms. Establishment of plants with reduced size is favorable in many crops ranging from fruit trees to 
annual bedding plants (Mayo 1987). Breeding strategies empowered by genetic engineering will lead to the development of more useful and productive crops for plant breeders. While transferring genes to plants for being resistant against diseases and insects, they might have been affected in other ways having altered properties (Oono et al. 1987; Spena et al. 1987; Schmulling et al. 1988; Fladung 1990; Smigocki and Hammerschlag 1991; Scorza et al. 1994). Legumes are not only providing a main source of protein and oil for human and animal nutrition but also contributing to the biological fixation of nitrogen. Moreover, a better understanding of plant-microbe interactions such as symbiotic nitrogen fixation, mycorrhizal associations, and legume-pathogen interactions can be possible with legume studies (Chilton et al. 1982; Christey 2001). Studies on aspects of hairy roots in legumes showed that proliferous root growth and abundant lateral branching are important for improving nitrogen fixation (Cheng et al. 1992).

Most plant structures, such as the hypocotyl, leaf, stem, stalk, petiole, shoot tip, cotyledon, protoplast, storage root, and tuber, have shown capacity to be infected and genetically transformed by $A$. rhizogenes resulting in stimulation of hairy root formation (Mugnier 1988; Han et al. 1993; Bajrovic et al. 1995; Arican et al. 1998; Drewes and Staden 1995; Giri et al. 2001; Krolicka et al. 2001; Azlan et al. 2002; Veena and Taylor 2007). Applications of plant biotechnology favor hairy-root cultures because of their special properties such as fast growth, short doubling time, ease of maintenance, and ability to synthesize a range of chemical compounds and proteins. Hairy root cultures are usually able to produce the same compounds found in wild-type roots of the parent plant, without the loss of concentration (Kim et al. 2002; Veena and Taylor 2007). Above all, hairy roots have an ability to regenerate stable transgenic plants either by a process of somatic embryogenesis or adventitious bud formation, so that genetically modified generations can be achieved (Spano and Costantino 1982; Tepfer 1984; Han et al. 1993; Cho and Wildholm 2002).

It is also known that modification of the cell hormonal balances occurring in response to infection causes root formation at the infected site (Gaudin et al. 1994; Aarrouf et al. 2012). However, the response varies depending upon the strain and its interaction with the plant. One of the most important advantages is that hairy root formation can be used as a verification of transformation. The use of antibiotic resistance markers in the development of transgenic plants is given rise to substantial public attention because of their unknown effects (Christey 2001).

Hairy roots have been used for infection of bacteria, fungi and nematodes and shown to successfully complete their life cycles (Cho et al. 1998; Collier et al. 2005). The resistance genes of nematode have been studied through using hairy roots (Cai et al. 1995; Remeeus et al. 1998; Kifle et al. 1999; Hwang et al. 2000). Development of plants using hairy roots have become of interest because of great potential for building up tolerance to biotic stresses and abiotic stresses (Porter 1991). Hairy root cultures provide an advantage related with making possible the analysis of the changes in enzyme activities and their isoenzyme patterns (Messner and Boll 1993; Kärkönen et al. 2002; Talano et al. 2006).

A variety of dicotyledonous plants are susceptible to A. rhizogenes. As a result of stable transformation, root cultures have been established from a range of spe- 
cies of plants (Tepfer 1990). In 1997, Christey reported plant species that had been genetically modified produced from hairy roots of 60 different taxa, representing 51 species from 41 genera and 23 families including Pinaceae Fabaceae, Brassicaceae and Solanaceae Araliaceae, Caricaceae and Rutaceae. In 2001, it was reported that, transgenic plants have been derived via transgenesis using in 89 different taxa, representing 79 species from 55 genera and 27 families (Christey 2001). Because lack of susceptibility, monocotyledonous plants are not a host for A. rhizogenes for and still there is no example for transgenic monocotyledonous plant except onion (Dommisse et al. 1990) and asparagus (Hernalsteens et al. 1993; Christey 2001). According to Web of Science, currently there are more than 500 studies conducted on $A$. rhizogenes. Table 1.2 summarizes the studies conducted, the plants and the genes transferred via A. rhizogenes in chronological order.

\section{Conclusion and Future Perespective}

This chapter deals with current research on A. rhizogenes-mediated transformation and its applications in crops. A. rhizogenes is responsible for the development of hairy root disease in a wide range of dicotyledonous plants and characterized by a proliferation of excessively branching roots. Containing case studies demonstrating the result of $A$. rhizogenes-mediated transformation includes biosynthesis pathways in plants created a valuable platform in the last years. Furthermore, the plants transformed with $A$. rhizogenes are become increasingly popular for offering approaches to create cost-effective options in mass-producing desired plant metabolites and expressing foreign proteins. The data from numerous proof-of-concept studies including improved the nutritional quality, agronomical characteristics, production of plant-derived products encourages for the realization of scaling up Agrobacterium based practices. Recently, transgenic plants produced by Agrobacterium-mediated transformation have also been shown to have immense potential for applications in phytoremediation. This chapter highlights recent progresses in the field of $A$. rhizogenes-mediated transformation and outlines future perspectives for the exploitation of it.

Acknowledgement Authors are grateful to Professor Nermin Gözükırmızı, Professor Şule Ari, Associate Professor Ercan Arican and Dr. Neslihan Turgut-Kara at Istanbul University, Department of Molecular Biology and Genetics for providing hairy root pictures of their previous studies and Agrobacterium rhizogenes strains (8196 and R1000) which had been given by Associate Professor Kemal Melik Taşkın (Çanakkale 18 Mart University, Biology Department) to Istanbul University Data Collection. Then there were those people at Marmara University, School of Medicine, Department of Histology and Embryology who helped with techniques for obtaining SEM micrographs. We are grateful to all of them, in particular to: Professor Feriha Ercan, Research Assistant Özlem T. Çilingir and Yücel Öztürk. We like to acknowledge Designer Recep Cenk Tarhan and Biologist-Designer İlke Ertem who spent hours of their time helping with the figures and diagrams, Research Assistants Sezen İğdelioğlu and Onur Zorluer for assistance with compiling the references. 
Table 1.2 Summary of the studies conducted, the plants and the genes transferred via A.rhizogenes in chronological order

\begin{tabular}{|c|c|c|c|}
\hline$\overline{\text { Daucus carota }}$ & Carrot & rol & David et al. 1984 \\
\hline Kalanchoe daigremontiana & Devil's backbone & rol & White et al. 1985 \\
\hline Arabidopsis thaliana & Mouse ear cress & rol & Pavingerova and Ondrej 1986 \\
\hline Cucumis sativus & Cucumber & NPTII & Trulson et al. 1986 \\
\hline Lycopersicon esculentum & Tomato & NPTII & Shahin et al. 1986 \\
\hline Petunia hybrida & Petunia & rol & Ondrej and Biskova 1986 \\
\hline Armoracia lapathifolia & Horseradish & rol & Noda et al. 1987 \\
\hline Lycopersicon peruvianum & - & NPTII & Morgan et al. 1987 \\
\hline Nicotiana debneyi & Debney's tobacco & NPTII & Davey et al. 1987 \\
\hline Nicotiana plumbaginifolia & - & NPTII & Davey et al. 1987 \\
\hline Solanum nigrum & Black nightshade & NPTII & Davey et al. 1987 \\
\hline Anagallis arvensis & Pimpernel & rol & Mugnier 1988 \\
\hline Convolvulus arvensis & Morning glory & rol & Mugnier 1988 \\
\hline Foeniculum vulgare & Fennel & rol & Mugnier 1988 \\
\hline Linum usitatissimum & Flax & rol & Zhan et al. 1988 \\
\hline Nicotiana glauca & Tree tobacco & rol & Sinkar et al. 1988 \\
\hline Nicotiana hesperis & - & rol & Walton and Belshaw 1988 \\
\hline $\begin{array}{l}\text { Brassica oleracea var. } \\
\quad \text { acephala }\end{array}$ & Ornamental kale & rol & Hosoki et al. 1989 \\
\hline Catharanthus roseus & Periwinkle & rol & Brillanceau et al. 1989 \\
\hline Glycine argyrea & Wild soybean & NPTII & Rech et al. 1989 \\
\hline Glycine canescens & Wild soybean & NPTII & Rech et al. 1989 \\
\hline Lotus corniculatus & Bird's-Foot trefoil & GUS & Forde et al. 1989 \\
\hline Solanum tuberosum & Potato & NPT II, GUS & Visser et al. 1989 \\
\hline Stylosanthes humilis & Townsville stylo & NPT II & Manners and way 1989 \\
\hline Trifolium repens & White clover & rol & Diaz et al. 1989 \\
\hline Brassica napus & Rapeseed & NPTII & Boulter et al. 1990 \\
\hline Nicotiana rustica & Mapacho & ODS & Hamill et al. 1990 \\
\hline Nicotiana tabacum & Tobacco & NPTII & Hatamoto et al. 1990 \\
\hline Vicia faba & Fava bean & NPTII & Ramsay and Kumar 1990 \\
\hline Actinidia deliciosa & Kiwifruit & rol & Rugini et al. 1991 \\
\hline Allocasuarina verticillata & Drooping she-oak & rol & Phelep et al. 1991 \\
\hline Cichorium intybus & Chicory & rol & Sun et al. 1991 \\
\hline Hyoscyamus muticus & Egyptian henbane & rol & $\begin{array}{l}\text { Oksman-Caldentey et al. } \\
1991\end{array}$ \\
\hline Medicago arborea & Tree medick & HPT & Damiani and Aricioni 1991 \\
\hline Medicago sativa & Alfalfa/lucerne & rol & Golds et al. 1991 \\
\hline Olea europaea & Olive & rol & Rugini et al. 1996 \\
\hline Onobrychis viciifolia & Sainfoin & rol & Golds et al. 1991 \\
\hline Pistacia vera & Pistachio & rol & Rugini and Mariotti 1991 \\
\hline Malus domestica & Apple & rolB & Rugini and Mariotti 1991 \\
\hline Solanum dulcamara & Nightshade & NPTII, rol & McInnes et al. 1991 \\
\hline Anthyllis vulneraria & Kidney vetch & NPTII, ipt & Stiller et al. 1992 \\
\hline Atropa belladonna & Deadly nightshade & bar & Saito et al. 1992 \\
\hline Brassica campestris & Turnip & NPT II & Christey and Sinclair 1992 \\
\hline
\end{tabular}


Table 1.2 (continued)

\begin{tabular}{|c|c|c|c|}
\hline $\begin{array}{l}\text { Brassica campestris var. } \\
\text { rapifera }\end{array}$ & Turnip & $\begin{array}{l}\text { GUS, NPTII, } \\
\text { ALS }\end{array}$ & Christey and Sinclair 1992 \\
\hline $\begin{array}{l}\text { Brassica oleracea var. } \\
\quad \text { acephala }\end{array}$ & Forage kale & $\begin{array}{l}\text { GUS, NPTII, } \\
\text { ALS }\end{array}$ & Christey and Sinclair 1992 \\
\hline Malus pumila & Apple & rol & Lambert and Tepfer 1992 \\
\hline Medicago truncatula & Barrel clover & NPTII & Thomas et al. 1992 \\
\hline Papaver somniferum & Opium poppy & rol & $\begin{array}{l}\text { Yoshimatsu and Shimomura } \\
1992\end{array}$ \\
\hline Coffea arabica & Coffea & rol & Spiral et al. 1993 \\
\hline Eucalyptus sp. & Eucalyptus & rol & MacRae and van Staden 1993 \\
\hline Glycine $\max$ & Soybean & GUS & Olhoft et al. 2007 \\
\hline Ipomoea batatas & Sweet potato & NPTII, GUS & Otani et al. 1993 \\
\hline $\begin{array}{l}\text { Populus trichocarpa } \times \\
\text { P. deltoides }\end{array}$ & Cottonwood & NPTII & Han et al. 1993 \\
\hline Robinia pseudoacacia & Black locust & NPTII & Han et al. 1993 \\
\hline Vicia hirsuta & Hairy vetch & rol & Quandt et al. 1993 \\
\hline Vigna aconitifolia & Moth bean & SbPRP1 & $\begin{array}{l}\text { Suzuki et al. 1993; Lee et al. } \\
1993\end{array}$ \\
\hline Diospyros kaki & $\begin{array}{l}\text { Japanese } \\
\text { persimmon }\end{array}$ & rol & Tao et al. 1994 \\
\hline Larix decidua & European larch & $\begin{array}{l}\text { NPTII, aroA, } \\
\text { BT }\end{array}$ & Shin et al. 1994 \\
\hline Pelargonium graveolens & Lemon geranium & rol & Pellegrineschi et al. 1994 \\
\hline Rosa hybrida & Hybrid tea rose & NPTII, GUS & Firoozabady et al. 1994 \\
\hline Rubia peregrina & Wild madder & ICS & Downs et al. 1994 \\
\hline Vinca minor & Lesser periwinkle & NPTII, GUS & Tanaka et al. 1994 \\
\hline Vitis vinifera & Grapevine & NPTII, GUS & Nakano et al. 1994 \\
\hline Casuarina glauca & Swamp she-oak & GUS & Diouf et al. 1995 \\
\hline Gentiana scabra & Japanese gentian & rol & Suginuma and Akihama 1995 \\
\hline Solanum tuberosum L. & Potato & rol & Bajrovic et al. 1995 \\
\hline Rudbeckia hirta & Black-Eyed susan & rol & Daimon and Mii 1995 \\
\hline Verticordia grandis & $\begin{array}{l}\text { Scarlet } \\
\quad \text { featherflower }\end{array}$ & NPTII, GUS & Stummer et al. 1995 \\
\hline Citrus sinensis & Sweet orange & rol & Li et al. 1996 \\
\hline Ajuga reptans & Blue bugle & GUS & Uozumi et al. 1996 \\
\hline Begonia tuberhybrida & Begonia & rol & Kiyokawa et al. 1996 \\
\hline Brassica campestris & Turnip & GUS & Christey et al. 1997 \\
\hline Brassica oleracea & Wild cabbage & GUS & Christey et al. 1997 \\
\hline Carica papaya & Papaya & NPTII, GUS & Cabrera-Ponce et al. 1996 \\
\hline Eustoma grandiflorum & Lisianthus & NPTII, GUS & Handa 1992 \\
\hline Ipomoea trichocarpa & $\begin{array}{l}\text { Blue morning } \\
\text { glory }\end{array}$ & NPTII, GUS & Otani et al. 1993 \\
\hline Juglans regia & Walnut & rolB & Caboni et al. 1996 \\
\hline Lotus angustissimus & $\begin{array}{l}\text { Slender bird's-foot } \\
\text { trefoil }\end{array}$ & NPTII, GUS & Nenz et al. 1996 \\
\hline Pelargonium fragrans & Nutmeg geranium & rol & $\begin{array}{l}\text { Pellegrineschi and Davolio- } \\
\text { Mariani } 1996\end{array}$ \\
\hline
\end{tabular}


Table 1.2 (continued)

\begin{tabular}{|c|c|c|c|}
\hline $\begin{array}{l}\text { Pelargonium } \\
\text { odoratissimum }\end{array}$ & Apple geranium & rol & $\begin{array}{l}\text { Pellegrineschi and Davolio- } \\
\text { Mariani } 1996\end{array}$ \\
\hline Pelargonium quercifolium & $\begin{array}{l}\text { Oak-Leaved } \\
\text { geranium }\end{array}$ & rol & $\begin{array}{l}\text { Pellegrineschi and Davolio- } \\
\text { Mariani } 1996\end{array}$ \\
\hline Pinus contorta & Lodgepole pine & rol & Yibrah et al. 1996 \\
\hline Pinus halepensis & Aleppo pine & rol & Tzfira et al. 1996 \\
\hline Pinus nigra & Austrian pine & rol & Mihaljevic et al. 1996 \\
\hline Populus tremula & Aspen & NPTII, GUS & Tzfira et al. 1996 \\
\hline Rosa sp. & Rose & rol & Van der Salm et al. 1997 \\
\hline Scoparia dulcis & Licorice weed & rol & Yamazaki et al. 1996 \\
\hline Aconitum heterophyllum & Indian atees & rol & Giri et al. 1997 \\
\hline Artemisia аппиа & Sweet wormwood & rol & Banerjee et al. 1997 \\
\hline Brassica napus & Oilseed rape & $\begin{array}{l}\text { GUS, NPTII, } \\
\text { ALS }\end{array}$ & Christey et al. 1997 \\
\hline Brassica oleracea & Wild cabbage & GUS, NPTII & Christey et al. 1997 \\
\hline Datura arborea & Angel's trumpets & rol & Giovannini et al. 1997 \\
\hline Datura sanguinea & $\begin{array}{r}\text { Red Angel's } \\
\text { trumpets }\end{array}$ & rol & Giovannini et al. 1997 \\
\hline Digitalis lanata & Grecian foxglove & rol & Pradel et al. 1997 \\
\hline Gentiana cruciata & Gentian & GUS & Momčilović et al. 1997 \\
\hline Gentiana purpurea & Purple gentian & rol & Momčilović et al. 1997 \\
\hline $\begin{array}{l}\text { Gentiana triflora } \times G \text {. } \\
\quad \text { scabra }\end{array}$ & - & rol & Hosokawa et al. 1997 \\
\hline Lotus japonicus & Lotus japonicus & rol & Stiller et al. 1997 \\
\hline Nierembergia scoparia & Tall cupflower & rol & Godo et al. 1997 \\
\hline Peganum harmala & Harmal & TDS & Berlin et al. 1993 \\
\hline Antirrhinum majus & Snapdragon & bar, NPTII & Hoshino and Mii 1998 \\
\hline Arachis hypogaea L. & Groundnut & rol & Akasaka et al. 1998 \\
\hline Astragalus sinicus & Chinese milk vetch & GUS & Cho et al. 1998 \\
\hline Citrus aurantifolia & Mexican lime & NPTII, GUS & $\begin{array}{l}\text { Pérez-Molphe-Balch and } \\
\text { Ochoa-Alejo } 1998\end{array}$ \\
\hline Nicotiana spp. & - & rol & Palazon et al. 1998 \\
\hline Panax ginseng & Ginseng & rol & Yang and Choi 2000 \\
\hline Prunus avium & Sweet cherry & rol & Gutierrez-Pesce et al. 1998 \\
\hline $\begin{array}{l}\text { Brassica campestris var. } \\
\text { pekinensis }\end{array}$ & Chinese cabbage & NPTII, EAS & Christey et al. 1999 \\
\hline $\begin{array}{l}\text { Brassica oleracea L. var. } \\
\quad \text { italica }\end{array}$ & Broccoli & rol & Henzi et al. 1999 \\
\hline $\begin{array}{l}\text { Brassica oleracea var. } \\
\quad \text { botrytis }\end{array}$ & Cauliflower & NPTII, GUS & Christey et al. 1999 \\
\hline $\begin{array}{l}\text { Brassica oleracea var. } \\
\text { capitata }\end{array}$ & Cabbage & NPTII, GUS & Christey et al. 1999 \\
\hline $\begin{array}{l}\text { Brassica oleracea var. } \\
\quad \text { gemmifera }\end{array}$ & Brussels sprouts & NPTII & Christey et al. 1999 \\
\hline $\begin{array}{l}\text { Brassica oleracea var. } \\
\quad \text { italica }\end{array}$ & Broccoli & NPTII, EAS & Christey et al. 1999 \\
\hline Gentiana punctata & Spotted gentian & GUS & Vinterhalter et al. 1999 \\
\hline Pimpinella anisum & Anise & rol & Andarwulan and Shetty 1999 \\
\hline Pyrus communis & Pear & rolC & Bell et al. 1999 \\
\hline
\end{tabular}


Table 1.2 (continued)

\begin{tabular}{|c|c|c|c|}
\hline Rubia tinctorum & Common madder & rol & Ercan et al. 1999 \\
\hline Ulmus spp. & Elm & rol & Rinallo et al. 1999 \\
\hline Ziziphus jujuba & Jujube & rol & Hatta et al. 1996 \\
\hline Crotalaria juncea & Sunn hemp & rol & Ohara et al. 2000 \\
\hline Trifolium pratense & Red clover & rol & Díaz et al. 2000 \\
\hline $\begin{array}{l}\text { Brassica napus var. } \\
\text { rapifera }\end{array}$ & Swede (Rutabaga) & bar & Christey and Braun 2001 \\
\hline Oryza sativa var. japonica & Japanese Rice & rolA, NPTII & Lee et al. 2001 \\
\hline Spinacia oleracea & Spinach & rol & Ishizaki et al. 2002 \\
\hline Citrus aurantium & Bergamot orange & rol & Chavez-Vela et al. 2003 \\
\hline Ginkgo biloba & Ginkgo & rol & $\begin{array}{l}\text { Ayadi and Tremouillaux- } \\
\text { Guiller } 2003\end{array}$ \\
\hline Rauvolfia micrantha & - & rol & Sudha et al. 2003 \\
\hline Sesbania rostrata & Pea & rol & Van de Velde et al. 2003 \\
\hline Aesculus hippocastanum & Horse-chestnut & GUS & Zdravkovic-Korac et al. 2004 \\
\hline Alstroemeria sp. & Peruvian lily & $\begin{array}{l}\text { NPTII, GUS, } \\
\text { rol }\end{array}$ & Akutsu et al. 2004 \\
\hline Camptotheca acuminata & Happy tree & rol & Lorence et al. 2004 \\
\hline Genista tinctoria & Greenweed & rol & $\begin{array}{l}\text { Luczkiewicz and } \\
\text { Kokotkiewicz } 2005\end{array}$ \\
\hline Typha latifolia & Common bulrush & rol & Nandakumar et al. 2005 \\
\hline $\begin{array}{l}\text { Brassica oleracea var. } \\
\text { sabauda }\end{array}$ & Savoy cabbage & GUS & Sretenovic-Rajicic et al. 2006 \\
\hline $\begin{array}{l}\text { Brassica oleracea var. } \\
\quad \text { sabauda }\end{array}$ & Savoy cabbage & rol & Sretenovic-Rajicic et al. 2006 \\
\hline Eustoma grandiflorum & Lisianthus & rol & Popa et al. 2006 \\
\hline Echinacea purpurea & Purple coneflower & rolB & Wang et al. 2006 \\
\hline Phaseolus vulgaris & Common bean & GFP, GUS & Estrada-Navarrete et al. 2006 \\
\hline Tylophora indica & Indian ipecac & rol & Chaudhuri et al. 2006 \\
\hline Asimina triloba & Pawpaw & rolB, C & Ayala-Silva et al. 2007 \\
\hline Pueraria candollei & - & rolB & Medina-Bolivar et al. 2007 \\
\hline Beta vulgaris & Red beet & NPTII & Thimmaraju et al. 2008 \\
\hline Glycyrrhiza glabra & Licorice & rol & Mehrotra et al. 2008 \\
\hline Musa sp. & Banana & rol & Matsumoto et al. 2009 \\
\hline Plumbago rosea & Plumbago & rol & Satheeshkumar et al. 2009 \\
\hline Podophyllum hexandrum & $\begin{array}{l}\text { Himalayan } \\
\text { mayapple }\end{array}$ & rol & Lin et al. 2003 \\
\hline Psoralea corylifolia & Babchi & rol & Shinde et al. 2009 \\
\hline Drosera burmannii & Tropical sundew & rol & Putalun et al. 2010 \\
\hline Echium rauwolfii & Echium rauwolfii & rol & Abd El-Mawla 2010 \\
\hline Fagopyrum esculentum & Buckwheat & GUS & Kim et al. 2010 \\
\hline Mangifera indica & Mango & rol & Chavarri et al. 2010 \\
\hline Przewalskia tangutica & - & rol & Lan and Quan 2010 \\
\hline Corchorus capsularist & Jute & GUS & Chattopadhyay et al. 2011 \\
\hline Nasturtium officinale & Watercresses & rol & Park et al. 2011 \\
\hline Prunus sp. & - & Egfp, NPTII & Bosselut et al. 2011 \\
\hline Amaranthus spinosus & Spiny amaranth & rolB & Pal et al. 2012 \\
\hline Capsicum annuum & Pepper & GFP & Aarrouf et al. 2012 \\
\hline Clitoria ternatea & Butterfly pea & rol & Swain et al. 2012 \\
\hline
\end{tabular}




\section{References}

Aarrouf J, Castro-Quezada P, Mallard S, Caromel B, Lizzi Y, Lefebvre V (2012) Agrobacterium rhizogenes-dependent production of transformed roots from foliar explants of pepper (Capsicum annuиm): a new and efficient tool for functional analysis of genes. Plant Cell Rep 31:391-401

Abarca-Grau AM, Penyalver R, Lopez MM, Marco-Noales E (2011) Pathogenic and non-pathogenic Agrobacterium tumefaciens, A. rhizogenes and A. vitis strains form biofilms on abiotic as well as on root surfaces. Plant Pathol 60:416-425

Abd El-Mawla AMA (2010) Effect of certain elicitors on production of pyrrolizidine alkaloids in hairy root cultures of Echium rauwolfii. Pharmazie 65:224-226

Ackermann C (1977) Pflanzen aus Agrobacterium rhizogenes tumoren and Nicotiana tabacum. Plant Sci Lett 8:23-30

Akasaka Y, Mii M, Daimon H (1998) Morphological alterations and root nodule formation in Agrobacterium rihzogenes-mediated transgenic hairy roots of peanut (Arachis hypogaea L.). Ann Bot 81:355-362

Akutsu M, Ishizaki T, Sato H (2004) Transformation of the monocot Alstroemeria by Agrobacterium rhizogenes. Mol Breeding 13:69-78

Alpizar E, Dechamp E, Espeout S, Royer M, Lecouls AC, Nicole M, Bertrand B, Lashermes P, Etienne H (2006) Efficient production of Agrobacterium rhizogenes-transformed roots and composite plants for studying gene expression in coffee roots. Plant Cell Rep 25:959-967

Altamura MM, Tomassi M (1998) Auxin, photoperiod and putrescine affect flower eoformation in normal and rolB-transformed tobacco thin cell layers. Plant Physiol Biochem 36:441-448

Andarwulan N, Shetty K (1999) Phenolic synthesis in differentiated tissue cultures of untransformed and Agrobacterium-transformed roots of anise (Pimpinella anisum L.). J Agric Food Chem 47:1776-1780

Aoki S, Syono K (1999) Short communication synergistic function of rolB, rolC, ORF13 and ORF14 of $\mathrm{T}_{\mathrm{L}}$-DNA of Agrobacterium rhizogenes in hairy root induction in Nicotiana tabacum. Plant Cell Physiol 40(2):252-256

Arican E, Bajrovic K, Gozukirmizi N (1998) Effects of naphthalene acetic acid on transformation frequency of potato and tobacco via Agrobacterium rhizogenes. Biotechnol Biotec Eq 12(1):29-33

Ayadi R, Tremouillaux-Guiller J (2003) Root formation from transgenic calli of Ginkgo biloba. Tree Physiol 23:713-718

Ayala-Silva T, Bey CA, Dortch G (2007) Agrobacterium rhizogenes mediated transformation of Asimina triloba L. cuttings. Pak J Biol Sci 10:132-136

Azlan GJ, Marziah M, Radzali M, Johari (2002) Establishment of Physalis minima hairy roots culture for the production of physalins. Plant Cell Tiss Org 69:271-278

Bajrovic K, Arı Ş, Arıcan E, Kazan K, Gözükırmızı N (1995) Biotechnol Biotec Eq 1:29-32

Balandrin MF, Klocke JA, Wurtele ES, Bollinger WH (1985) Natural plant chemicals: sources of industrial and medicinal materials. Science 228:1154-1160

Bandyopadhyay M, Jha S, Tepfer D (2007) Changes in morphological phenotypes and withanolide composition of Ri-transformed roots of Withania somnifera. Plant Cell Rep 26:599-609

Banerjee S, Zehra M, Gupta MM, Kumar S (1997) Agrobacterium rhizogenes mediated transformation of Artemisia annua -production of transgenic plants. Planta Med 63:467-469

Bellincampi D, Cardarelli M, Zaghi D, Serino G, Salvi G, Gatz C, Cervone F, Altamura MM, Constantino P, De-Lorenzo G (1996) Oligogalacturonides prevent rhizogenesis in rolB transformed tobacco explants by inhibiting auxin-induced expression of the rolB gene. Plant Cell 8:477-487

Bell RL, Scorza R, Srinivasan C, Webb K (1999) Transformation of 'Beurre Bosc' pear with the rolC gene. J Arner Soc Hort Sci 124:570-574

Bensaddek L, Villarreal ML, Fliniaux MA (2008) Induction and growth of hairy roots for the production of medicinal compounds. Electron J Integr Biosci 3(1):2-9 
Berlin J, Ruegenhagen C, Dietze P, Fecker LF, Goddijn OJM, Hoge JHC (1993) Increased production of seratonin by suspension and root cultures of Peganum harmala transformed with a tryptophan decarboxylase cDNA clone from Cathranthus roseus. Transgenic Res 2:336-344

Bettini P, Michelotti S, Bindi D, Giannini R, Capuana M, Buiatti M (2003) Pleiotropic effect of the insertion of the Agrobacterium rhizogenes rolD gene in tomato (Lycopersicon esculentum Mill.). Theor Appl Genet 107:831-836

Binns AN, Costantino P (1998) The Agrobacterium oncogenes. In: Spaink HP, Kondorosi A, Hooykaas PJ (eds) The Rhizobiaceae: molecular biology of model plant-associated bacteria. Kluwer Academic Publishers, Dordrecht, pp. 251-266

Binns AN, Chen RH, Wood HN, Lynn DG (1987) Cell division promoting activity of naturally occurring dehydrodiconiferyl glucosides: do cell wall components control cell division? Proc Natl Acad Sci USA 84:980-984

Birch RG (1997) Plant transformation: problems and strategies for practical application. Annu Rev Plant Physiol Plant Mol Biol 48:297-326

Block M (1993) The cell biology of plant transformation: current state, problems, prospects and the implications for the plant breeding. Euphytica 71(1-2):1-14

Bonhomme V, Laurain-Mattar D, Lacoux J, Fliniaux MA, Jacquin-Dubreuil A (2000) Tropane alkaloid production by hairy roots of Atropa belladonna obtained after transformation with Agrobacterium rhizogenes 15834 and Agrobacterium tumefaciens containing rolA, B, C genes only. J Biotech 81(2-3):151-158

Bosselut N, Van Ghelder C, Claverie M, Voisin R, Onesto JP, Rosso MN, Esmenjaud D (2011) Agrobacterium rhizogenes-mediated transformation of Prunus as an alternative for gene functional analysis in hairy-roots and composite plants. Plant Cell Rep 30(7):1313-1326

Bouchez D, Camilleri C (1990) Identification of a putative rolB gene on the TR-DNA of the Agrobacterium rhizogenes A4 Ri plasmid. Plant Mol Biol 14:617-619

Boulter ME, Croy E, Simpson P, Shields R, Croy RRD, Shirsat AH (1990) Transformation of Brassica napus L. (oilseed rape) using Agrobacterium tumefaciens and Agrobacterium rhizogenes- a comparison. Plant Sci 70:91-99

Brevet J, Tempe J (1988) Homology mapping of T-DNA regions on three Agrobacterium rhizogenes Ri plasmids by electron microscope heteroduplexstudies. Plasmid 19:75-83

Brillanceau MH, David C, Tempê̂ J (1989) Genetic transformation of Catharanthus roseus G. Don by Agrobacterium rhizogenes. Plant Cell Rep 8:63-66

Britton MT, Escobar MA, Dandekar M (2008) The oncogenes of Agrobacterium tumefaciens and Agrobacterium rhizogenes. In: Tzfira T, Citovsky V (eds) Agrobacterium: from biology to biotechnology. Springer, Heidelberg, pp. 525-563

Broothaerts W, Mitchell HJ, Weir B, Kaines S, Smith LMA, Yang WM, Jorge E, Roa-rodriguez CJ, Richard A (2005) Gene transfer to plants by diverse species of bacteria. Nature 433:629-633

Bulgakov VP (2008) Functions of rol genes in plant secondary metabolism. Biotechnol Adv 26:318-324

Bulgakov VP, Khodakovskaya MV, Labetskaya NV, Tchernoded GK, Zhuravlev YN (1998) The impact of plant rolC oncogene on ginsenoside production by ginseng hairy root cultures. Phytochemistry 49:1929-1934

Bulgakov VP, Tchernoded GK, Mischenko NP, Khodakovskaya MV, Glazunov VP, Zvereva EV, Fedoreyev SA, Zhuravlev YN (2002a) Effect of salicylic acid, methyl jasmonate, ethephon and cantharidin on anthraquinone production by Rubia cordifolia callus cultures transformed with the rolB and rolC genes. J Biotechnol 97:213-221

Bulgakov VP, Kusaykin M, Tchernoded GK, Zvyagintseva TN, Zhuravlev YN (2002b) Carbohydrase activities of the rolC-gene transformed and non-transformed ginseng cultures. Fitoterapia 73:638-643

Bulgakov VP, Tchernoded GK, Mischenko NP, Shkryl YN, Fedoreyev SA, Zhuravlev YN (2004) The rolB and rolC genes activate synthesis of anthraquinones in Rubia cordifolia cells by mechanism independent of octadecanoid signaling pathway. Plant Sci 166:1069-1075

Caboni E, Lauri P, Tonelli M, Falasca G, Damiano C (1996) Root induction by Agrobacterium rhizogenes in walnut. Plant Sci 118:203-208 
Cabrera-Ponce JL, Vegas-Garcia A, Herrera-Estrella L (1996) Regeneration of transgenic papaya plants via somatic embryogenesis induced by Agrobacterium rhizogenes. In Vitro Cell Dev Biol Plant 32:86-90

Cai G, Li G, Ye H (1995) Hairy root culture of Artemisia annua L. by Ri plasmid transformation and biosynthesis of artemisinin. Chinese J Biotechnol 11(4):227-235

Camilleri C, Jouanin L (1991) The TR-DNA region carrying the auxin synthesis genes of the Agrobacterium rhizogenes agropine type plasmid pRiA4: nucleotide sequence analysis and introduction into tobacco plants. Mol Plant Microbe Interact 4:155-162

Capone IL, Spano L, Cardarelli M, Bellincampi D, Petit A, Constantino P (1989) Induction and growth properties of carrot roots with different complements of Agrobacterium rhizogenes TDNA genes. Plant Mol Biol 13:43-52

Cardarelli M, Spanò L, De Paolis A, Mauro ML, Vitali G, Costantino P (1985) Identification of the genetic locus responsible for non-polar root induction by Agrobacterium rhizogenes 1855. Plant Mol Biol 5:385-391

Cardarelli M, Mariotti D, Pomponi M, Spano L, Capone I, Costantino P (1987a) Agrobacterium rhizogenes T-DNA genes capable of inducing hairy root phenotype. Mol Gen Genet 209(3):475-480

Cardarelli M, Spano L, Mariotti D, Mauro ML, Van Sluys MA, Costantino P (1987b) The role of auxin in hairy root induction. Mol Gen Genet 208:457-463

Casanova E, Zuker A, Trillas MI, Moysset L, Vainstein A(2003) The rolC gene in carnation exhibits cytokinin- and auxin-like activities. Sci Hortic 97:321-331

Casanova E, Valdes AE, Zuker A, Fernandez B, Vainstein A, Trillas MI, Moysset L (2004) rolCtransgenic carnation plants: adventitious organogenesis and levels of endogenous auxin and cytokinins. Plant Sci 167(3):551-560

Census (2012) The official website of U.S. Department of Commerce, U.S. Census Bureau-World POPClock Projection. http://www.census.gov. Accessed: 25. May 2011

Chandra S (2012) Natural plant genetic engineer Agrobacterium rhizogenes: role of T-DNA in plant secondary metabolism. Biotechnol Lett 34(3):407-415

Charlwood BV, Charlwood KA (1991) Terpenoid production in plant cell culture. In: Harborne JB, Tomas-Barberan FE (eds) Ecological chemistry and biochemistry of plant terpenoids. Clarendon Press, Oxford, pp 95-132

Chattopadhyay T, Roy S, Mitra A, Maiti MK (2011) Development of a transgenic hairy root system in jute (Corchorus capsularis L.) with GUSA reporter gene through Agrobacterium rhizogenes mediated co-transformation. Plant Cell Rep 30(4):485-493

Chaudhuri KN, Ghosh B, Tepfer D, Jha S (2006) Spontaneous plant regeneration in transformed roots and calli from Tylophora indica: changes in morphological phenotype and tylophorine accumulation associated with transformation by Agrobacterium rhizogenes. Plant Cell Rep 25(10):1059-1066

Chavarri M, García AV, Zambrano AY, Gutiérrez Z, Demey JR (2010) Insertion of Agrobacterium rhizogenes rolB gene in Mango. Interciencia 35(7):521-525

Chavez-Vela NA, Chavez-Ortiz LI, Perez-Molphe Balch E (2003) Genetic transformation of sour orange using Agrobacterium rhizogenes. Agrociencia 37:629-639

Cheng M, His DCH, Philips GC (1992) In vitro regeneration of Valencia type peanut (Arachis hypogaea L.) from cultured petioles, epicotyl, sections and other seedling explants. Peanut Sci 19:82-87

Chilton MD, Tepfer D, Petit A, David C, Delbart C-F, Tempt J (1982) Agrobacterium rhizogenes inserts T-DNA into the genomes of the host plant root cells. Nature 295:432-434

Cho HJ, Wildholm JM (2002) Improved shoot regeneration protocol for hairy roots of the legume Astragalus sinicus. Plant Cell Tiss Org 69:259-269

Cho H-J, Widholm JM, Tanaka N, Nakanishi Y, Murooka Y (1998) Agrobacterium rhizogenesmediated transformation and regeneration of the legume Astragalus sinicus (Chinese milk vetch). Plant Sci 138:53-65 
Christensen B, Sriskandarajah S, Serek M, Müller R (2008) Transformation of Kalanchoe blossfeldiana with rol-genes is useful in molecular breeding towards compact growth. Plant Cell Rep 27:1485-1495

Christey MC (2001) Use of Ri-mediated transformation for production of transgenic plants. In Vitro Cell Dev Biol Plant 37:687-700

Christey MC, Braun RH (2001) Transgenic vegetable and forage Brassica species: rape, kale, turnip and rutabaga (Swede). In: Bajaj YPS (ed) Biotechnology in agriculture and forestry, Transgenic crops II 47:87-101

Christey MC, Braun RH, Reader JK (1999) Field performance of transgenic vegetable brassicas (Brassica oleracea and B. rapa) transformed with Agrobacterium rhizogenes. Sabrao J Breed Genet 31:93-108

Christey MC, Sinclair BK (1992) Regeneration of trasgenic kale (Brassica oleracea var. acephal), rap (B. napus) and turnip (B. campestris var rapifera) plants via Agrobacterium rhizogenes mediated transformation. Plant Sci 87:161-169

Christey MC, Sinclair BK, Braun RH, Wyke L (1997) Regeneration of transgenic vegetable brassicas (Brassica oleracea and B. campestris) via Ri-mediated transformation. Plant Cell Rep 16:587-593

Christie PJ, Ward JE, Winans SC, Nester EW (1988) The Agrobacterium tumefaciens virE2 gene product is a single-stranded- DNA-binding protein that associates with T-DNA. J Bacteriol 170:2659-2667

Christou P (1997) Biotechnology applied to grain legumes. Field Crop Res 53:83-97

Chuck G, Lincoln C, Hake S (1996) KNAT1 induces lobed leaves with ectopic meritems when overexpressed in Arabidopsis. Plant Cell 8:1277-1289

Citovsky V, Zupan J, Warnick D, Zambryski P (1992) Nuclear localization of Agrobacterium VirE2 protein in plant cells. Science 256:1802-1805

Collier R, Fuchs B, Walter N, Kevin LW, Taylor CG (2005) Ex vitro composite plants: an inexpensive, rapid method for root biology. Plant J 43:449-457

Comai L, Kosuge T (1982) Cloning and characterization of iaaM, a virulence determinant of Pseudomonas savastanoi. J Bacteriol 149:40-46

Conn HJ (1942) Validity of the genus Alcaligenes. J Bacteriol 44:353-360

Costantion P, Spano L, Pomponi M, Benevuto E, Ancora G (1984) The T-DNA of Agrobacterium rhizogenes is transmitted through meiosis to the progeny of hairy root plants. J Mol Appl Genet 2(5):465-470

Costantino P, Capone I, Cardarelli M, De-Paolis A, Mauro ML, Trovato M (1994) Bacterial plant oncogenes: the rol genes' saga. Genetica 94:203-211

Daimon H, Mii M (1995) Plant regeneration and thiophene production in hairy root cultures of Rudbeckia hirta L. used as an antagonistic plant to nematodes. Jpn J Crop Sci 64:650-655

Damiani F, Aricioni S (1991) Transformation of Medicago arborea L. with Agrobacterium rhizogenes binary vector carrying the hygromycin resistance genes. Plant Cell Rep 10:300-303

Davey MR, Mulligan BJ, Gartland KMA, Peel E, Sargent AW, Morgan AJ (1987) Transformation of Solanum and Nicotiana species using an Ri plasmid vector. J Exp Bot 38:1507-1516

David C, Chilton MD, Tempe J (1984) Conservation of T-DNA in plants regenerated from hairy root cultures. Biotech 2:73-76

Davioud E, Petit A, Tate ME, Ryder MH, Tempe J (1988) Cucumopine-a new T-DNA-encoded opine in hairy root and crown gall. Phytochemistry 27(8):2429-2433

De Paolis A, Mauro ML, Pompon M, Cardarelli M, Spano L, Costantino P (1985) Localization of agropine synthesizing functions in the TR region of the root inducing plasmid of Agrobacterium rhizogenes 1855 . Plasmid 13:1-7

Dehio C, Grossmann K, Schell J, Schmülling T (1993) Phenotype and hormonal status of transgenic tobacco plants overexpressing the rolA gene of Agrobacterium rhizogenes T-DNA. Plant Mol Biol 23(6):1199-1210

Dehio C, Schell J (1993) Stable expression of a single-copy rolA gene in transgenic Arabidopsis thaliana plants allows an exhaustive mutagenic analysis of the transgene-associated phenotype. Mol Gen Genet 241:359-366 
Delbarre A, Muller P, Imhoff V, Barbier-Brygoo H, Maurel C, Leblanc N, Perrot-Rechenmann C, Guern J (1994) The rolB Gene of Agrobacterium rhizogenes does not increase the auxin sensitivity of tobacco protoplasts by modifying the intracellular auxin concentration. Plant Physiol 105:563-569

Dessaux Y, Petit A, Tempe J (1992) Opines in Agrobacterium biology. In: Verma DPS (ed) Molecular signals in plant-microbe communications. CRC Press, Boca Raton, pp 109-136

Diaz CL, Melchers LS, Hooykaas PJJ, Lugtenberg BJJ, Kijne JW (1989) Root lectin as a determinant of host-plant specificity in the Rhizobium-legume symbiosis. Nature 338:579-581

Díaz Cl, Spaink HP, Kijne JW (2000) Heterologous rhizobial lipchitin oligosaccharides and chitin oligomers induce cortical cell divisions in red clover roots, transformed with the pea lectin gene. Mol Plant Microbe Interact 13:268-276

Diouf D, Gherbi H, Prin Y, Franche C, Duhoux E, Bogusz D (1995) Hairy root nodulation of Casuarina glauca: a system for the study of symbiotic gene expression in an actinorhizal tree. Mol Plant Microbe Interact 8:532-537

Dodueva IE (2007) A Study of expression of the genes involved in systemic control of cell division and differentiation in higher plants on the model of spontaneous tumorigenesis in inbred radish lines (Raphanus sativus var. radicula Pers.). Cand Sci (Biol) Dissertation, St. Petersburg: Gos. Univ

Dommisse EM, Leung DWM, Shaw ML, Conner AJ (1990) Onion is a monocotyledonous host for Agrobacterium. Plant Sci 69:249-257

Doran PM (2002) Properties and applications of hairy root cultures. In: Marja K, Caldentey KM, Barz W (eds) Plant biotechnology and transgenic plants. Marcel Dekker Inc, New York, pp $1-20$

Downs CG, Christey MC, Davies KM, King GA, Seelye JF, Sinclair BK, Stevenson DG (1994) Hairy roots of Brassica napus: II glutamine synthase over expression alters ammonia assimilation and the response to phosphinothricin. Plant Cell Rep 14:41-46

Drewes FE, Staden JV (1995) Initiation of and solasodine production in hairy root cultures of Solanum mauritianum. Scop Plant Growth Regul 17:27-31

Duckely M, Hohn B (2003) The VirE2 protein of Agrobacterium tumefaciens: the Yin and Yang of T-DNA transfer. FEMS Microbiol Lett 223:1-6

Durand-Tardif M, Broglie R, Slightom J, Tepfer D (1985) Structure and expression of Ri T-DNA from Agrobacterium rhizogenes in Nicotiana tabacum. J Mol Biol 186:557-564

Ephritikhine G, Barbier-Brygoo H, Muller JF, Guern J (1987) Auxin effect on the transmembrane potential difference of wild-type and mutant tobacco protoplasts exhibiting a differential sensitivity to auxin. Plant Physiol 83:801-804

Ercan AG, Taski KM, Turgut K, Yuce S (1999) Agrobacterium rhizogenes-mediated hairy root formation in some Rubia tinctorum L populations grown in Turkey. Turk J Bot 23:373-378

Estrada-Navarrete G, Alvarado-Affantranger X, Olivares JE, Diaz-Camino C, Santana O, Murillo E, Guillen G, Sanchez-Guevara N, Acosta J, Quinto C, Li DX, Gresshoff PM, Sanchez F (2006) Agrobacterium rhizogenes transformation of the Phaseolus spp: a tool for functional genomics. Mol Plant Microb Interact 19:1385-1393

Estramareix C, Ratet P, Boulanger F, Richaud F (1986) Multiple mutations in the transferred regions of the Agrobacterium rhizogenes root-inducing plasmids. Plasmid 15:245-247

Estruch JJ, Chriqui D, Grossmann K, Schell J, Spena A (1991) The plant oncogene rolC is responsible for the release of cytokinins from glucoside conjugates. EMBO J 10:2889-2895

Faiss M, Strnad M, Redig P, Dolzak K, Hanus J, Van Onckelen H, Schmuelling T (1996) Chemically induced expression of the rol cencoded $\beta$-glucuronidase in transgenic tobacco plants and analysis of cytokinin metabolism: RolC does not hydrolyze endogenous cytokinin glucosides in planta. Plant J 10:33-46

Filetici P, Spano L, Costantino P (1987) Conserved regions in the T-DNA of different Agrobacterium rhizogenes root inducing plasmid. Plant Mol Biol 9:19-26

Filichkin SA, Gelvin SB (1993) Formation of a putative relaxation intermediate during T-DNA processing directed by Agrobacterium tumefaciens VirD1/D2 endonuclease. Mol Microbiol 8:915-926 
Filippini F, Lo Schiavo F, Terzi M, Costantino P, Trovato M (1994) The plant oncogene rolB alters binding of auxin to plant cell membranes. Plant Cell Physiol 35:767-771

Filippini F, Rossi V, Marin O, Trovato M, Costantino P, Downey PM, Lo Schiavo F, Terzi M (1996) A plant oncogene as a phosphatase. Nature 379:499-500

Firoozabady E, Moy Y, Courtney-Gutterson N, Robinson K (1994) Regeneration of transgenic rose (Rosa hybrida) plants from embryogenic tissue. Bio/Technology 12:609-613

Fladung M (1990) Transformation of diploid and tetraploid potato clones with the rolC gene of Agrobacterium rhizogenes and the characterization of transgenic plants. Plant Breeding 104:295-304

Flores HE, Vivanco JM, Loyola-Vargas VM (1999) Radicle biochemistry: the biology of rootspecific metabolism. Trends Plant Sci 4:220-226

Forde BG, Day HM, Turton JF, Shen WJ, Cullimore V, Oliver JE (1989) Two glutamine synthase genes from Phaseolus vulgaris L. display contrasting developmental and spatial patterns of expression in transgenic Lotus corniculatus plants. Plant Cell 1:391-401

Frundt C, Meyer AD, Ichikawa T, Meins FJ (1998) Evidence for the ancient transfer of Ri plasmid T-DNA genes between bacteria and plants. In: Syvanen M, Kado CI (eds) Horizontal gene transfer. Chapman and Hall, London, pp 94-106

Gartland JS (1995) Agrobacterium virulence. In: Gartland KMA, Davey MR (eds) Methods in molecular biology 44 Agrobacterium protocols. Humana Press, New Jersey

Gaudin V, Jouanin L (1995) Expression of Agrobacterium rhizogenes auxin biosynthesis genes in transgenic tobacco plants. Plant Mol Biol 28:123-36

Gaudin V, Vrain T, Jouanin L (1994) Bacterial genes modifying hormonal balances in plants. Plant Physiol Biochem 32:11-29

Gelvin SB (1998) Agrobacterium VirE2 proteins can form a complex with T strands in the plant cytoplasm. J Bacteriol 180:4300-4302

Gelvin SB (2003) Improving plant genetic engineering by manipulating the host. Trends Biotechnol 21:95-98

Gelvin SB (2009) Agrobacterium in the genomics age. Plant Physiol 150:1665-1676

Gepts P (2002) A Comparison between crop domestication, classical plant breeding, and genetic engineering. Crop Sci 42:1780-1790

Giovannini A, Pecchioni N, Rabaglio M, Allavena A (1997) Characterization of ornamental datura plants transformed by Agrobacterium rhizogenes. In Vitro Cell Dev Biol Plant 33:101-106

Giri A, Banerjee S, Ahuja PS, Giri CC (1997) Production of hairy roots in Aconitum heterophyllum wall using Agerobacterium rhizogenes. In Vitro Cell Dev Biol Plant 33:280-284

Giri A, Giri CC, Dhingra V, Narasu ML (2001) Enhanced podophyllotoxin production from Agrobacterium rhizogenes transformed cultures of Podophyllum hexandrum. Nat Prod Lett 15:229-235

Giri A, Narasu ML (2000) Research review paper transgenic hairy roots: recent trends and applications. Biotechnol Adv 18:1-22

Giri CC, Giri A (2007) Plant biotechnology. Practical Manual I International Publishing House Pvt. Ltd., New Delhi, pp 69-76

Golds TJ, Lee JY, Husnain T, Ghose TK, Davey MR (1991) Agrobacterium rhizogenes mediated transformation of the forage legumes Medicago sativa and Onobrychis viciifolia. J Exp Bot 42:1147-1157

Gorpenchenko TY, Kiselev KV, Bulgakov VP, Tchernoded GK, Bragina EA, Khodakovskaya MV, Koren OG, Batygina TB, Zhuravlev YN (2006) The Agrobacterium rhizogenes rolC-gene induced somatic embryogenesis and shoot organogenesis in Panax ginseng transformed calluses. Planta 22:3457-3467

Graham LA, Liou YC, Walker VK, Davies PL (Aug 1997) Hyperactive antifreeze protein from beetles. Nature 388(6644):727-728

Grant JE, Dommisse EM, Conner AJ (1991) Gene transfer to plants using Agrobacterium. In: Murray DR (ed) Advanced methods in plant breeding and biotechnology. CAB International, Wallingford, pp 50-73 
Gutierrez-Pesce P, Taylor K, Muleo R, Rugini E (1998) Somatic embryogenesis and shoot regeneration from transgenic roots of the cherry root stock colt (Prunus avium, P. pseudocerasus) mediated by pRi 1855 T-DNA of Agrobacterium rhizogenes. Plant Cell Rep 17:574-580

Guyon P, Chilton M-D, Petit A, Tempe J (1980) Agropine in "null-type" crown gall tumors: evidence for generality of the opine concept. Proc Natl Acad Sci 77:2693-2697

Guyon P, Petit A, Tempe J, Dessau Y (1993) Transformed plants producing opines specifically promote growth of opine-degrading agrobacteria. Mol Plant Microb Interact 6:92-98

Hamill JD, Robins RJ, Parr AJ, Evans PM, Furze JD, Rhodes MJC (1990) Over expressing a yeast ornithine decarboxylase gene in transgenic roots of Nicotiana rustica can lead to enhanced nicotine accumulation. Plant Mol Biol 15:27-38

Han KH, Keathley DE, Davis JM, Gordon MP (1993) Regeneration of a transgenic woody legume Robinia pseudoacacia L, (Black locust) and morphological alterations induced by Agrobacterium rhizogenes mediated transformation. Plant Sci 88:149-57

Handa T (1992) Regneration and charaterization of prairie gentian (Eustoma grandiflorum) plants transformed by Agrobacterium rhizogenes. Plant Tiss Cult Lett 9:10-14.

Hansen G, Larribe M, Vaubert D, Tempe J, Biermann BJ, Montoya AL, Chilton MD, Brevet J (1991) Agrobacterium rhizogenes pRi8196 T-DNA: mapping and DNA sequence of functions involved in mannopine synthesis and hairy root differentiation (Ri plasmid). Proc Natl Acad Sci 88:7763-7767

Hansen G, Vaubert D, Heron JN, Clerot D, Tempe J, Brevet J (1993) Phenotypic effects of overexpression of Agrobacterium rhizogenes T-DNA ORF13 in transgenic tobacco plants are mediated by diffusible factor(s). Plant J 4:581-585

Hansen G, Das A, Chilton MD (1994a) Constitutive expression of the virulence genes improves the efficiency of plant transformation by Agrobacterium. Proc Nat Acad Sci 91:7603-7607

Hansen G, Vaubert D, Clerot D, Tempe J, Brevet J (1994b) A new open reading frame, encoding a putative regulatory protein, in Agrobacterium rhizogenes T-DNA. C R Acad Sci III 317:49-53

Hansen G, Vaubert D, Clerot D, Brevet J (1997) Wound-inducible and organ-specific expression of ORF13 from Agrobacterium rhizogenes 8196 T-DNA in transgenic tobacco plants. Mol Gen Genet 254(3):337-343.

Hasancebi S, Turgut Kara N, Cakir O, Ari S (2011) Micropropagation and root culture of Turkish endemic Astragalus chrysochlorus (Leguminosae). Turk J Bot 35:203-210

Hatamoto H, Boulter ME, Shirsat AH, Croy EJ, Ellis JR (1990) Recovery of morphologically normal transgenic tobacco from hairy roots co-transformed with Agrobacterium rhizogenes and a binary vector plasmid. Plant Cell Rep 9:88-92

Hatta M, Beyl CA, Garton S, Diner AM (1996) Induction of roots on jujube softwood cuttings using Agrobacterium rhizogenes. J Hortic Sci 71(6):881-886

Hauptmann RM, Ozias-Akins P, Vasil V, Tabaeizadeh Z, Rogers SG, Horsch RB, Vasil IK, Fraley RT (1987) Transient expression of electroporated DNA in monocotyledonous and dicotyledonous species. Plant Cell Rep 6(4):265-270

Henzi MX, Christey MC, McNeil DL, Davies KM (1999) Agrobacterium rhizogenes-mediated transformation of broccoli (Brasica oleracea L. var italica) with an antisense 1-aminocyclopropane-1-carboxylic acid oxidase gene. Plant Sci 143:55-62

Hernalsteens JP, Bytebier B, Van Montagu M (1993) Transgenic asparagus. In: Kung SD, Wu R (eds) Transgenic plants, present status and social and economic impacts, vol 2. San Diego, Academic Press pp 35-46

Hiei Y, Ohta S, Komari T, Kumashiro T (1994) Efficient transformation of rice (Oryza sativa L) mediated by Agrobacterium and sequence analysis of the boundaries of the T-DNA. Plant $\mathbf{J}$ 6:271-282

Hildebrand E (1934) Life history of the hairy-root organism in relation to its pathogenesis on nursery apple trees. J Agric Res 48:857-885

Hirotaka K, Hiroshi K (2003) Gene silencing by expression of hairpin RNA in Lotus japonicus roots and root nodules. Mol Plant Microbe Interact 16:663-668 
Hodges LD, Cuperus J, Ream W (2004) Agrobacterium rhizogenes GALLS protein substitutes for Agrobacterium tumefaciens single- stranded DNA-binding protein VirE2. J Bacteriol 186:3065-3007

Hodges LD, Vergunst AC, Neal-McKinney J, den Dulk-Ras A, Moyer DM, Hooykaas PJ, Ream W (2006) Agrobacterium rhizogenes GALLS protein contains domains for ATP binding, nuclear localization, and type IV secretion. J Bacteriol 188:8222-8230

Holefors A, Xue ZT, Welander M (1998) Transformation of the apple rootstock M26 with the rolA gene and its influence on growth. Plant Sci 136:69-78

Hong S-B, Hwang I, Dessaux Y, Guyon P, Kim K-S, Farrand SK (1997) A T-DNA gene required for agropine biosynthesis by transformed plants is functionally and evolutionarily related to a Ti plasmid gene required for catabolism of agropine by Agrobacterium strains. J Bacteriol 179:4831-4840

Hong SB, Peebles CA, Shanks JV, San KY, Gibson SI (2006) Terpenoid indole alkaloid production by Catharanthus roseus hairy roots induced by Agrobacterium tumefaciens harboring rolABC genes. Biotechnol Bioeng 93:386-390

Hoshino Y, Mii M (1998) Bialaphos stimulates shoot regeneration from hairy roots of snapdragon (Antirrhinum majus L.) transformed by Agrobacterium rhizogenes. Plant Cell Rep 17:256-261

Hosokawa K, Matsuki R, Oikawa Y, Yamamura S (1997) Genetic transformation of gentian using wild-type Agrobacterium rhizogenes. Plant Cell Tiss Org Cult 51:137-140

Hosoki T, Shiraishi K, Kigo T, Ando M (1989) Transformation and regeneration of ornamental kale (Brassica oleracea var. Acephala DC) mediated by Agrobacterium rhizogenes. Sci Hort 40:259-266

$\mathrm{Hu} \overline{\mathrm{ZB}, \mathrm{Du} M}$ (2006) Hairy root and its application in plant genetic engineering. J Int Plant Biol 48:121-127

Huffman GA, White FF, Gordon MP, Nester EW (1984) Hairy-root-inducing plasmid: physical map and homology to tumor-inducing plasmids. J Bacteriol 157:269-276

Hwang CF, Bhakta AV, Truesdell GM, Pudlo WM, Williamson VM (2000) Evidence for a role of the $\mathrm{N}$ terminus and leucine-rich repeat region of the $M i$ gene product in regulation of localized cell death. Plant Cell 12:1319-1329

Inze D, Follin A, Van Lijsebettens M, Simoens C, Genetello C, Van Montagu M, Schell J (1984) Genetic analysis of the individual T-DNA genes of Agrobacterium tumefaciens; further evidence that two genes are involved in indole-3-acetic acid synthesis. Mol Gen Genet 194:265-274

Ishizaki T, Hoshino Y, Masuda K, Oosawa K (2002) Explants of Ri-transformed hairy roots of spinach can develop embryogenic calli in the absence of gibberellic acid, an essential growth regulator for induction of embryogenesis from nontransformed roots. Plant Sci 163:223-231

Isogai A, Fukuchi N, Hayashi M, Kamada H, Harada H, Suzuki A (1988) Structure of a new opine, mikimopine, in hairy root induced by Agrobacterium rhizogenes. Agric Bio and Chem 52:3235-3237

Jacobs M, Rubery PH (1988) Naturally occurring auxin transport regulators. Science 241:346-349

James C (2006) Global Status of Commercialized Biotech/GM Crops: 2006. ISAAA Briefs No. 35. ISAAA (International Service for the Acquisition of Agri-Biotech Applications). Ithaca, New York

Jouanin L (1984) Restriction map of an agropine-type Ri plasmid and its homologies to Ti plasmids. Plasmid 12:91-102

Jouanin L, Guerche P, Pamboukdjian N, Tourneur C, Casse Delbart F, Tourneur J (1987a) Structure of T-DNA in plants regenerated from roots transformed by Agrobacterium rhizogenes strain A4. Mol Gen Genet 206(3):387-392

Jouanin L, Vilaine F, Tourneur J, Tourneur C, Pautot V, Muller JF, Caboche M (1987b) Transfer of a 4.3-kb fragment of the $\mathrm{T}_{\mathrm{L}}$-DNA of Agrobacterium rhizogenes strain $\mathrm{A} 4$ confers the $\mathrm{pRi}$ transformed phenotype to rege nerated tobacco plants. Plant Sci 53:53-63

Kärkönen A, Koutaniemi S, Mustonen M, Syrjänen K, Brunow G, Kilpeläinen I, Teeri TH, Simola LK (2002) Lignification related enzymes in Picea abies suspension cultures. Physiol Plant $114: 343-353$ 
Keil M (2002) Fine chemicals from plants. In: Marja K, Caldentey KM, Barz W (eds) Plant biotechnology and transgenic plants. Marcel Dekker Inc, New York, pp 1-20

Keller CP, Van Volkenburgh E (1998) Evidence that auxin-induced growth of tobacco leaf tissues does not involve cell wall acidification. Plant Physiol 118:557-564

Kersters K, De Ley J (1984) Genus III Agrobacterium Conn 1942 In Bergey's Manual of Systematic Bacteriology, vol 1. In: Krieg NR, Holt JG (eds) Baltimore: Williams \& Wilkins, pp 244-254

Kifle S, Shao M, Jung C, Cai D (1999) An improved transformation protocol for studying gene expression in hairy roots of sugar beet (Beta vulgaris L). Plant Cell Rep 18:514-519

Kim YJ, Weathers PJ, Wyslouzil BE (2002) The growth of Artemisia annua hairy roots in liquid and gas phase reactors. Biotechnol Bioeng 80:454-464

Kim YK, Hui X, Park WT, Park NI, Young LS, Park SU (2010) Genetic transformation of buckwheat (Fagopyrum esculentum M.) with Agrobacterium rhizogenes and production of rutin in transformed root cultures. Aust J Crop Sci 4(7):485-490s

Kiselev KV, Dubrovina AS, Veselova MV, Bulgakov VP, Fedoreyev SA, Zhuravlev YN (2007) The rolB gene-induced overproduction of resveratrol in Vitis amurensis transformed cells. J Biotechnol 128:681-692

Kiyokawa S, Kobayashi K, Kikuchi Y, Kamada H, Harada H (1994) Root-inducing of mikimopine type Ri plasmid pRi1724. Plant Physiol 104:801-802

Kiyokawa S, Kikuchi Y, Kamada H, Harada H (1996) Genetic transformation of Begonia tuberhybrida by Ri rol genes. Plant Cell Rep 15:606-609

Klee HJ, Horsch RB, Hinchee MA, Hein MB, Hoffmann NL (1987) The effect of over production of two Agrobacterium tumefaciens T-DNA auxin biosynthetic gene products in transgenic Petunia plants. Genes Dev 1:86-89

Koltunow AM, Johnson SD, Lynch M, Yoshihara T, Costantino P (2001) Expression of rolB in apomictic Hieracium piloselloides Vill. causes ectopic meristems in planta and changes in ovule formation, where apomixis initiates at higher frequency. Planta 214:196-205

Krolicka A, Staniszewska II, Bielawski K, Malinski E, Szafranek J, Lojkowska E (2001) Establishment of hairy root cultures of Ammi majus. Plant Sci 160:259-264

Kuiper HA, Kleter GA, Noteborn HPJM, Kok EJ (2001) Assessment of the food safety issues related to genetically modified foods. The Plant J 27(6):503-528

Kumar V, Sharma A, Prasad BCN, Gururaj HB, Ravishankar GA (2006) Agrobacterium rhizogenes mediated genetic transformation resulting in hairy root formation is enhanced by ultrasonication and acetosyringone treatment. Electron J Biotech 9(4):349-357

Lahners K, Byrne MC, Chilton MD (1984) T-DNA fragments of hairy root plasmid pRi8196 are distantly related to octopine and nopaline Ti plasmid T-DNA. Plasmid 11:130-140

Lambert C, Tepfer D (1992) Use of Agrobacterium rhizogenes to create transgenic apple trees having an altered organogenic response to hormones. Theor Appl Genet 85:105-109

Lan XZ, Quan H (2010) Hairy root culture of Przewalskia tangutica for enhanced production of pharmaceutical tropane alkaloids. J Med Plants Res 4:1477-1481

Leach F, Aoyagi K (1991) Promoter analysis of the highly expressed rolC and rolD root-inducing genes of Agrobacterium rhizogenes: enhancer and tissue-specific DNA determinants are dissociated. Plant Sci 79:69-76

Lee NG, Stein B, Suzuki H, Verma DPS (1993) Expression of antisense nodulin-35 RNA in $\mathrm{Vi}$ gna aconitifolia transgenic root nodules retards peroxisome development and affects nitrogen availability to the plant. Plant J 3:599-606

Lee S, Blackhall NW, Power JB, Cocking EC, Tepfer D, Davey MR (2001) Genetic and morphological transformation of rice with the rolA gene from the Ri $\mathrm{T}_{\mathrm{L}}$-DNA of Agrobacterium rhizogenes. Plant Sci 161:917-925

Lemcke K, Schmulling T (1998) Gain of function assays identify non-rol genes from Agrobacterium rhizogenes $\mathrm{T}_{\mathrm{L}}$-DNA that alter plant morphogenesis or hormone sensitivity. Plant $\mathrm{J}$ 15(3):423-433

Lemcke K, Prinsen E, Van Onckelen H, Schmülling T (2000) The ORF8 gene product of Agrobacterium rhizogenes $\mathrm{T}_{\mathrm{L}}$-DNA has tryptophan 2-monooxygenase activity. Mol Plant Microbe Interact 13:787-790 
Lessard PA, Kulaveerasingam H, York GM, Strong A, Sinskey AJ (2002) Manipulating gene expression for the metabolic engineering of plants. Metab Eng 4:67-79

Levesque H, Delepelaire P, Rouze P, Slightom J, Tepfer D (1988) Common evolutionary origin of the central portions of the Ri T $\mathrm{L}_{\mathrm{L}}$-DNA of Agrobacterium rhizogenes and the Ti T-DNAs of Agrobacterium tumefaciens. Plant Mol Biol 11:731-744

Li N, Huxtable S, Yang SF, Kung SD (1996) Effects of N-terminal deletions on 1-minocyclopropane-1-carboxylate synthase activity. FEBS Lett 378:286-290

Li D, Zhang Y, Hu X, Shen X, Ma L, Su Z, Wang T, Dong J (2011) Transcriptional profiling of Medicago truncatula under salt stress identified a novel CBF transcription factor MtCBF4 that plays an important role in abiotic stress responses. BMC Plant Biology 11:109-138

Limami A, Sun LY, Douat C, Helgeson J, Tepfer D (1998) Natural genetic transformation by Agrobacterium rhizogenes. Plant Physiol 118:543-550

Lin HW, Kwok KH, Doran PM (2003) Production of podophyllotoxin using cross-species coculture of Linum flavum hairy roots and Podophyllum hexandrum cell suspensions. Biotechnol Bioeng 19:1417-1426

Lorence A, Medina-Bolivar F, Nessler CL (2004) Camptothecin and 10-hydroxycamptothecin from Camptotheca acuminata hairy roots. Plant Cell Rep 22:437-441

Luczkiewicz M, Kokotkiewicz A (2005) Genista tinctoria hairy root cultures for selective production of isoliquiritigenin. Z Naturforsch 60c:867-875

MacRae S, Van Staden J (1993) Agrobacterium rhizogenes-mediated transformation to improve rooting ability of eucalypts. Tree Physiol 12:411-418

Manners JM, Way H (1989) Efficient transformation with regeneration of the tropical pasture legume Stylosanthes humilis using Agrobacterium rhizogenes and a Ti plasmid-binary vector system. Plant Cell Rep 8:341-345

Martin-Tanguy J (2001) Metabolism and function of polyamines in plants: recent development (new approaches). Plant Growth Regul 34:135-148

Martin-Tanguy J, Sun LY, Burtin D, Vernoy R, Rossin N, Tepfer D (1996) Attenuation of the phenotype caused by the root-inducing, left-hand, transferred DNA and its rolA gene. Plant Physiol 111:259-267

Matsumoto K, Cabral GB, Teixeira JB, Monte DC (2009) Agrobacterium-mediated transient expression system in banana immature fruits. Afr J Biotechnol 8(17):4039-4042

Maurel C, Barbier-Brygoo H, Spena A, Tempe J, Guern J (1991) Single rol genes from the Agrobacterium rhizogenes $\mathrm{T}_{\mathrm{L}}$-DNA alter some of the cellular responses to auxin in Nicotiana tabacum. Plant Physiol 97(1):212-216

Maurel C, Leblanc N, Barbier-Brygoo H, Perrot-Rechenmann C, Bouvier-Durand M, Guern J (1994) Alterations of auxin perception in rolB-transformed tobacco protoplasts (time course of rolB mRNA expression and increase in auxin sensitivity reveal multiple control by auxin). Plant Physiol 105:1209-1215

Mauro ML, Trovato M, Paolis AD, Gallelli A, Costantino P, Altamura MM (1996) The plant oncogene rolD stimulates flowering in transgenic tobacco plants. Dev Biol 180:693-700

Mayo O (1987) The theory of plant breeding, 2nd edn. Clarendon Press, Oxford

McCullen CA, Binns AN (2006) Agrobacterium tumefaciens and plant cell interactions and activities required for interkingdom macromolecular transfer. Annu Rev Cell Dev Biol 22:101-127

McInnes E, Morgan AJ, Mulligan BJ, Davey MR (1991) Phenotypic effects of isolated pRiA4 TLDNA rol genes in the presence of intact TR-DNA in transgenic plants of Solanum dulcamara L. J Exp Bot 42(10):1279-1286

Medford J, Horgan R, El-Sawi Z, Klee HJ (1989) Alterations of endogenous cytokinins in transgenic plants using a chimeric isopentenyl transferase gene. Plant Cell 1:403-413

Medina-Bolivar F, Condori J, Rimando AM, Hubstenberger J, Shelton K, O'Keefe SF, Bennett S, Dolan MC (2007) Production and secretion of resveratrol in hairy root cultures of peanut. Phytochemistry 68:1992-2003

Mehrotra S, Kukreja AK, Kumar A, Khanuja SPS, Mishra BN (2008) Genetic transformation studies and scale up of hairy root culture of Glycyrrhiza glabra in bioreactor. Electron J Biotech 11(2):15 
Messner B, Boll M (1993) Elicitor-mediated induction of enzymes of ligninbiosynthesis and formation of lignin-like material in a cell suspension culture of spruce (Picea abies). Plant Cell Tiss Org 34:261-269

Meyer A, Tempe J, Costantino P (2000) Hairy root: a molecular overview functional analysis of Agrobacterium rhizogenes T-DNA genes. In: Stacey G, Keen N (eds) Plant-microbe interactions, vol 5. APS Press, Minnesota, pp 93-139

Miflin B (2000) Crop improvement in the 21st century. J Exp Biol 51(342):1-8

Mihaljevic S, Stipkovic S, Jelaska S (1996) Increase of root induction in Pinus nigra explants using Agrobacteria. Plant Cell Rep 15:610-614

Milly PCD, Dunne KA, Vecchia AV (2005) Global patterns of trends in streamflow and water availability in a changing climate. Nature 438:347-350

Mishra BN, Ranjan R (2008) Growth of hairy-root cultures in various bioreactors for the production of secondary metabolites. Biotechnol Appl Biochem 49:1-10

Morgan AJ, Cox PN, Turner DA, Peel E, Davey MR, Gartland KMA, Mulligan BJ (1987) Transformation of tomato using an Ri plasmid vector. Plant Sci 49:37-49

Moriguchi K, Maeda Y, Satou M, Hardayani NS, Kataoka M, Tanaka N, Yoshida K (2001) The complete nucleotide sequence of a plant root-inducing (Ri) plasmid indicates its chimeric structure and evolutionary relationship between tumor-inducing (Ti) and symbiotic (Sym) plasmids in Rhizobiaceae. J Mol Biol 307:771-784

Moritz T, Schmülling T (1998) The gibberellin content of rolA transgenic tobacco plants is specifically altered. J Plant Physiol 153:774-776

Moyano E, Fornalé S, Palazón J, Cusidó RM, Bonfill M, Morales C, Piñol MT (1999) Effect of Agrobacterium rhizogenes T-DNA on alkaloid production in Solanaceae plants. Phytochemistry 52(7):1287-1292

Momčilović I, Grubišić D, Kojić M, Nešković M (1997) Agrobacterium rhizogenes -mediated transformation and plant regeneration of four Gentiana species. Plant Cell Tiss Org Organ Cult 50(1):1-6

Mugnier AJ (1988) Establishment of new axenic hairy root lines by inoculation with Agrobacterium rhizogenes. Plant Cell Rep 7:9-12

Mugnier J (1997) Mycorrhizal interactions and the effects of fungicides, nematicides and herbicides on hairy root cultures. In: Doran PM (ed) Hairy roots: culture and applications. Harwood Academic Publishers, Amsterdam, pp 123-132

Murugesan S, Manoharan C, Vijayakumar R, Panneerselvam A (2010) Isolation and characterization of Agrobacterium rhizogenes from the root nodules of some leguminous. Intl J Microbiol Res 1(3):92-96

Nader BL, Taketa AT, Pereda-Miranda R, Villarreal ML (2006) Production of triterpenoids in liquid-cultivated hairy roots of Galphimia glauca. Planta Med 72:842-844

Nakamura T, Handa T, Oono Y, Kanaya K, Michikawa M, Uchimiya H (1988) Organ-specific mRNA in transgenic tobacco plants possessing T-DNA of Ri plasmids. Plant Sci 56:213-218

Nakano M, Hoshino Y, Mii M (1994) Regeneration of transgenic plants of grape vine (Vitis vinifera L.) via Agrobacterium rhizogenes mediated transformation of embryogenic calli. J Exp Bot 45(274):649-656

Nandakumar R, Suzanne LC, Rogers MD (2005) Agrobacterium-mediated transformation of the wetland monocot Typha latifolia L (Broadleaf cattail). Plant Cell Rep 23:744-750

Navarrete GE, Affantranger XAl, Olivares JE, Camino CD, Santana O, Murillo E, Guillen G, Guevara NS, Acosta J, Quinto C, Li D, Gresshoff PM, Sanchez F (2006) Agrobacterium rhizogenes transformation of the phaseolus spp.: a tool for functional genomics. Mol Plant Microbe Interact 19(12):1385-1393

Nemoto K, Hara M, Suzuki M, Seki H, Oka A, Muranaka T, Mano Y (2009) Function of the aux and rol genes of the Ri plasmid in plant cell division in vitro. Plant Signal Behav 4(12):1145-1147

Nenz E, Pupilli F, Paolocci F, Damiani F, Cenci CA, Arcioni S (1996) Plant regeneration and genetic transformation of Lotus angustissimus. Plant Cell Tiss Organ Cult 45:145-152 
Nilsson O, Crozier A, Schmülling T, Sandberg G, Olsson O (1993a) Indole-3-acetic acid homeostasis in transgenic tobacco plants expressing the Agrobacterium rhizogenes rolB gene. Plant J 3:681-689

Nilsson O, Moritz T, Imbault N, Sandberg G, Olsson O (1993b) Hormonal characterization of transgenic tobacco plants expressing the rolC gene of Agrobacterium rhizogenes $\mathrm{T}_{\mathrm{L}}$-DNA. Plant Physiol 102:363-371

Nilsson O, Little CH, Sandberg G, Olsson O (1996a) Expression of two heterologous promoters, Agrobacterium rhizogenes rolC and cauliflower mosaic virus 35S, in the stem of transgenic hybrid aspen plants during the annual cycle of growth and dormancy. Plant Mol Biol 31:887-895

Nilsson O, Moritz T, Sundberg B, Sandberg G, Olsson O (1996b) Expression of the Agrobacterium rhizogenes rolC gene in a deciduous forest tree alters growth and development and leads to stem fasciation. Plant Physiol 112:493-502

Nilsson O, Olsson O (1997) Getting to the root: the role of the Agrobacterium rhizogenes rol genes in the formation of hairy roots. Physiol Plant 100:463-473

Noda T, Tanaka N, Mano Y, Nabeshima S, Ohkawa H, Matsui C (1987) Regeneration of horseradish hairy roots incited by Agrobacterium rhizogenes infection. Plant Cell Rep 6:283-286

Ohara A, Akasaka Y, Daimon H, Mii M (2000) Plant regeneration from hairy roots induced by infection with Agrobacterium rhizogenes in Crotalaria juncea L. Plant Cell Rep 19:563-568

Oksman-Caldentey KM, KivelaĖ O, Hiltunen R (1991) Spontaneous shoot organogenesis and plant regeneration from hairy root cultures of Hyoscyamus muticus. Plant Sci 78:129-136

Olempska-Beer ZWS, Merker RI, Ditto MD, DiNovi MJ (2006) Food-processing enzymes from recombinant microorganisms-a review. Regul Toxicol Pharmacol 45:144-158

Olhoft PM, Bernal LM, Grist LB, Hill DS, Mankin SL, Shen Y, Kalogerakis M, Wiley H, Toren E, Song H-S, Hillebrand H, Jones T (2007) A novel Agrobacterium rhizogenes-mediated transformation method of soybean [Glycine $\max$ (L.) Merrill] using primary-node explants from seedlings. In Vitro Cell Dev Biol Plant 43:536-549

Ondrej M, Biskova R (1986) Differentiation of Petunia hybrida tissues transformed by Agrobacterium rhizogenes and Agrobacterium tumefaciens. Biol Plant 28:152-155

Ooms G, Twell D, Bossen ME, Hoge JHC, Burrell MM (1986) Developmental regulation of RI T $\mathrm{L}_{-}^{-}$ DNA gene expression in roots, shoots and tubers of transformed potato (Solanum tuberosum cv. Desiree). Plant Mol Biol 6:321-330

Oono Y, Kanaya K, Uchimiya H (1990) Early flowering in transgenic tobacco plants possessing the rolC gene of Agrobacterium rhizogenes Ri plasmid. Jpn J Genet 68:7-16

Oono Y, Handa T, Kanaya K, Uchimiya H (1987) The T $\mathrm{L}_{\mathrm{L}}$-DNA gene of Ri plasmids responsible for dwarfness of tobacco plants. Jpn J Genet 62:501-505

Otani M, Mu M, Handa T, Kamada H, Shimada T (1993) Transformation of sweet potato (Ipomoea batatus (L.) Lam.) plants by Agrobacterium rhizogenes. Plant Sci 94:151-159

Otten L, Helfer A (2001) Biological activity of the rolB-like 5' end of the A4-ORF8 gene from the Agrobacterium rhizogenes $\mathrm{T}_{\mathrm{L}}$-DNA. Mol Plant Microbe Interact 14:405-411

Ouartsi A, Clerot D, Meyer A, Dessaux Y, Brevet J, Bonfill M (2004) The T-DNA ORF8 of the cucumopine-type Agrobacterium rhizogenes Ri plasmid is involved in auxin response in transgenic tobacco. Plant Sci 166:557-567

Ozyigit II (2012) Agrobacterium tumefaciens and its use in plant biotechnology. In: Ashraf M, Ozturk M, Ahmad MSA, Aksoy A (eds) Crop production for agricultural improvement. Springer, The Netherlands, pp 317-361

Özcan S, Uranbey S, Sancak C, Parmaksiz İ, Gürel E, Babaoğlu M (2004) Agrobacterium aracılığıyla gen aktarımı. In: Özcan S, Gürel E, Babaoğlu M (eds) Bitki Biyoteknolojisi II (Plant biotechnology, II), Genetik Mühendisliği ve Uygulamaları (Genetic engineering and its applications), Cilt II, 2nd edn. SÜ Vakfi Yayınlari, Turkey, pp 112-159

Pal A., Swain SS, Mukherjee AK, Chand PK (2012) Agrobacterium $\mathrm{pRi} \mathrm{T}_{\mathrm{L}}-\mathrm{DNA}$ rolB and $\mathrm{T}_{\mathrm{R}_{-}^{-}}$ DNA opine genes transferred to the spiny Amaranth (Amaranthus spinos $\bar{u} s$ L.) - A nutraceutical crop. Food Technol Biotech (In press)

Palazon J, Cusido RM, Roig C, Pinol MT (1998) Expression of the rol gene and nicotine production in transgenic hairy roots and their regenerated plants. Plant Cell Rep 17:384-90 
Park N1, JK Kim, WT Park, JW Cho, YP Lim, SU Park (2011) An efficient protocol for genetic transformation of watercress (Nasturtium officinale) using Agrobacterium rhizogenes. Mol Biol Rep 38:4947-4953

Pavingerova D, Ondrej M (1986) Comparison of hairy root and crown gall tumors of Arabidopsis thaliana. Biol Plant 28:149-151

Pellegrineschi A, Davolio-Mariani O (1996) Agrobacterium rhizogenes-mediated transformation of scented geranium. Plant Cell Tiss Organ Cult 47:79-86

Pellegrineschi A, Damon JP, Valtorta N, Paillard N, Tepfer D (1994) Improvement of ornamental characters and fragrance production in lemon-scented geranium through genetic transformation by Agrobacterium rhizogenes. Nat Biotechnol 12:64-68

Pérez-Molphe-Balch E, Ochoa-Alejo N (1998) Regeneration of transgenic plants of Mexican lime from Agrobacterium rhizogenes-transformed tissues. Plant Cell Rep 17:591-596

Petersen SG, Stummann BM, Olesen P, Henningsen KW (1989) Structure and function of rootinducing (Ri) plasmids and their relation to tumor-inducing (Ti) plasmids. Physiol Plantarum 77:427-435

Petit A, David C, Dahl G, Ellis JG, Guyon P, Casse-Delbart FC, Tempe J (1983) Further extension of the opine concept: plasmids in Agrobacterium rhizogenes cooperate for opine degradation. Mol Gen Genet 19:204-214

Phelep M, Petit A, Martin L, Duhoux E, Tempe J (1991) Transformation and regeneration of a nitrogen-fixing tree, Allocasuarina verticillata Lam. Biotechnol 9:461-466

Popa G, Cornea C P, Brezeanu A (2006) Influence of different Agrobacterium rhizogenes strains on hairy roots induction in Eustoma grandiflorum. Roum Biotechnol Lett 11(1):2587-2592

Porter J (1991) Host range and implications of plant infection by Agrobacterium rhizogenes. Crc Cr Rev Plant Sci 10:387-421

Pradel H, Dumke-Lehmann U, Dietrich B, Luckner M (1997) Hairy root cultures of Digitalis lanata. Secondary metabolism and plant regeneration. J Plant Physiol 151:209-215

Prinsen E, Bytebier B, Hernalsteens JP, De Greef J, Van Onckelen H (1990) Functional expression of Agrobacterium tumefaciens T-DNA onc-genes in Asparagus crown gall tissues. Plant Cell Physiol 31:69-75

Prinsen E, Chriqui D, Vilaine F, Tepfer M, Van Onckelen H (1994) Endogenous phytohormones in tobacco plants transformed with Agrobacterium rhizogenes $\mathrm{pRi} \mathrm{T}_{\mathrm{L}}$-DNA genes. Plant Physiol 144:80-85

Putalun W, Udomsin O, Yusakul G, Juengwatanatrakul T, Sakamoto S, Tanaka H (2010) Enhanced plumbagin production from in vitro cultures of Drosera burmanii using elicitation. Biotechnol Lett 32:721-724

Quandt HJ, Pühler A, Broer I (1993) Transgenic root nodules of Vicia hirsuta a fast and efficient system for the study of gene expression in indeterminate-type nodules. Mol Plant Microbe Interact 6:699-706

Ramsay G, Kumar A (1990) Transformation of Vicia faba cotyledon and stem tissues Agrobacterium rhizogenes: infectivity and cytological studies. J Exp Bot 41:841-847

Rao AQ, Bakhsh A, Kiani S, Shahzad K, Shahid AA, Husnain T, Riazuddin S (2009) The myth of plant transformation. Biotechnol Adv 27:753-763

Rao SR, Ravishankar G (2002) Plant cell cultures: chemical factories of secondary metabolites. Biotechnol Adv 20:101-153

Ream W (2002) Agrobacterium genetics. In: Streips UN, Yasbin RE (eds) Modern Microbial Genetics, 2nd edn. Wille-Liss Inc., New York, pp 323-348

Rech EL, Golds TJ, Husnain T, Vainstein MH, Jones B, Hammat N, Mulligan BJ, Davey MR (1989) Expression of a chimaeric kanamycin resistance gene introduced into the wild soybean Glycine canescens using a cointegrate Ri plasmid vector. Plant Cell Rep 8:33-36

Remeeus PM, van Bezooijen J, Wijbrandi J, van Bezooijen J (1998) In vitro testing is a reliable way to screen the temperature sensitivity of resistant tomatoes against Meloidogyne incognita. In: Proceedings of 5th international symposium on crop protection, Universiteit Gent Belgium, vol 63, pp 635-640 
Riker AJ, Banfield WM, Wright WH, Keitt GW (1930) Studies on infectious hairy root of nursery apple trees. J Agric Res 41:507-540

Rinallo C, Mittempergher L, Frugis G, Mariotti D (1999) Clonal propagation in the genus Ulmus: improvement of rooting ability by Agrobacterium rhizogenes T-DNA genes. J Hortic Sci Biotechnol 74:502-506

Rossi L, Hohn B, Tinland B (1996) Integration of complete transferred DNA units is dependent on the activity of virulence E2 protein of Agrobacterium tumefaciens. Proc Natl Acad Sci USA 93:126-130

Rugh CL (2001) Mercury detoxification with transgenic plants and other biotechnological breakthroughs for phytoremediation. In Vitro Cell Dev Biol Plant 37:321-325

Rugini E, Mariotti D (1991) Agrobacterium rhizogenes T-DNA genes and rooting in woody species. Acta Hort 300:301-307

Rugini E, Pellegrineschi A, Mencuccini M, Mariotti D (1991) Increase of rooting ability in the woody species kiwi (Actinidia deliciosa A. Chev.) by transformation with Agrobacterium rhizogenes rol genes. Plant Cell Rep 10:291-295

Rugini E, Muganu M, Gutiérrez-Pesce P E, Lolletti D (1996) Comportamento vegeto-produttivo di alcune specie fruttifere transgeniche per il T-DNA e geni rol di Agrobacterium rhizogenes. Convegno SIGA, Workshop Organismi geneticamente modificati e resistenze genetiche, Bologna, pp 55-57

Ryder MH, Tate ME, Kerr A (1985) Virulence properties of strains of Agrobacterium on the apical and basal surfaces of carrot root discs. Plant Physiol 77:215-221

Saha P, Chakraborti D, Sarkar A, Dutta I, Basu D, Das S (2007) Characterization of vascularspecific RSs1 and rolC promoters for their utilization in engineering plants to develop resistance against hemipteran insect pests. Planta 226:429-442

Saito K, Yamazaki M, Anzai H, Yoneyama K, Murakoshi I (1992) Transgenic herbicide-resistant Atropa belladonna using an Ri plasmid vector and inheritance of the transgenic trait. Plant Cell Rep 11:219-224

Satheeshkumar K, Jose B, Sonia EV, Seeni S (2009) Isolation of morphovariants through plant regeneration in A. rhizogenes induced hairy root cultures of Plumbago rosea L. Indian J Biotechnol 8:435-441

Savka MA, Ravillion B, Noel GR, Farrand SK (1990) Induction of hairy roots on cultivated soybean genotypes and their use to propagate the soybean cyst nematode. Phytopathology 80(5):503-508.

Schmulling T, Schell J, Spena A (1988) Single genes from Agrobacterium rhizogenes influence plant development. EMBO J 7:2621-2629

Schmülling T, Fladung M, Grossmann K, Schell J (1993) Hormonal content and sensitivity of transgenic tobacco and potato plants expressing single rol genes of Agrobacterium rhizogenes T-DNA. Plant J 3:371-382

Schröder G, Waffenschmidt S, Weiler E, Schröder J (1984) The region of Ti plasmid codes for an enzyme synthesizing indole-3-acetic acid. Eur J Biochem 138:387-391

Scorza R, Zimmerman TW, Cordts JM, Footen KJ (1994) Horticultural characteristics of transgenic tobacco expressing the rolC gene from Agrobacterium. J Amer Soc Hort Sci 119(5):1091-1098

Sentoku N, Sato Y, Matsuoka M (2000) Overexpression of rice OSH genes induces ectopic shoots on leaf sheaths of transgenic rice plants. Dev Biol 220:358-364

Sevon N, Oksman-Caldentey KM (2002) Agrobacterium rhizogenes mediated transformation: root cultures as a source of alkaloids. Planta Med 68:859-868

Shahin EA, Sukhapinda K, Simpson RB, Spivey R (1986) Transformation of cultivated tomato by a binary vector in Agrobacterium rhizogenesis: transgenic plants with normal phenotypes harbor binary vector T-DNA but no Ri-plasmid T-DNA. Theor Appl Genet 72:770-777

Shen WH, Petit A, Guern J, Tempe J (1988) Hairy roots are more sensitive to auxin than normal roots. Proc Natl Acad Sci 85:3417-3421

Shen WH, Davioud E, David C, Barbier-Brygoo H, Tempe J, Guern J (1990) High sensitivity to auxin is a common feature of hairy root. Plant Physiol 94:554-560 
Shin DI, Podila GK, Huang Y, Karnosky DF (1994) Transgenic larch expressing genes for herbicide and insect resistance. Can J For Res 4:2059-2067

Shinde AN, Malpathak N, Fulzele PD (2009) Enhanced production of phytoestrogenic isoflavones from hairy root cultures of Psoralea corylifolia L. using elicitation and precursor feding. Biotechnol Bioprocess E 14:288-294

Shkryl YN, Veremeichik GN, Bulgakov VP, Tchernoded GK, Mischenko NP, Fedoreyev SA, Zhuravlev YN (2008) Individual and combined effects of the rolA, B and C genes on anthraquinone production in Rubia cordifolia transformed calli. Biotechnol Bioeng 100(1):118-125

Shoja HM (2010) Contribution to the study of the Agrobacterium rhizogenes plast genes, rolB and rolC, and their homologs in Nicotiana tabacum. Universite de Strasbourg, France

Sinha N, Williams R, Hake S (1993) Overexpression of the maize homeobox gene, KNOTTED-1, causes a switch from determinate to indeterminate cell fates. Genes Dev 7:787-795

Sinkar V, Pythoud F, White F, Nester E, Gordon M (1988) rolA locus of the Ri plasmid directs developmental abnormalities in transgenic plants. Genes Dev 2:688-697

Slightom JL, Durand-Tardif M, Jouanin L, Tepfer D (1986) Nucleotide sequence analysis of TLDNA of Agrobacterium rhizogenes agropine type plasmid. J Biol Chem 261:108-121

Smigocki AC, Hammerschlag FA (1991) Regeneration of plants from peach embryo cells infected with a shooty mutant strain of Agrobacterium. J Amer Soc Hort Sci 116:1092-1097

Smulders M JM, Croes AF, Kemp A, Hese KM, Harren F, Wullems GJ (1991) Inhibition by ethylene of auxin promotion of flower bud formation in tobacco explants is absent in plants transformed by Agrobacterium rhizogenes. Plant Physiol 96:1131-1135

Spano L, Costantino P (1982) Regeneration of plants from callus cultures of roots induced by Agrobacterium rhizogenes on tobacco. Z Pflanzenphysiol 106:87-92

Spano L, Mariotti D, Cardarelli M, Branca C, Costantino P (1988) Morphogenesis and auxin sensitivity of transgenic tobacco with different complements of Ri T-DNA. Plant Physiol 87(2):479-483

Specq A, Hansen G, Vaubert D, Clerot D, Heron JN, Tempe J, Brevet J (1994) Studies on hairy root T-DNA: regulation and properties of ORF13 from Agrobacterium rhizogenes 8196. In Plant Pathogenic Bacteria, Versailles, pp 465-468

Spena A, Schmulling T, Konct C, Schell JS (1987) Independent and synergistic activity of rolA, B and C loci in stimulating abnormal growth in plants. EMBO J 206(13):3891-3899

Spiral J, Thierry C, Paillard M, Petiard V. (1993) Obtention de plantules de Coffea canephora Pierre (Robusta) transformées par Agrobacterium rhizogenes. C R Acad Sci Hebd Seances Acad Sci 316:1-6

Sretenovic-Rajicic T, Ninkovi S, Miljus-Dukic J, Vinterhalter B, Vinterhalter D (2006) Agrobacterium rhizogenes-mediated transformation of Brassica oleracea var. sabauda and B. oleracea var. capitata. Biol Plant 50:525-530

Stieger PA, Meyer AD, Kathmann P, Fründt C, Niederhauser I, Barone M, Kuhlemeier C (2004) The orf13 T-DNA Gene of Agrobacterium rhizogenes confers meristematic competence to differentiated cells. Plant Physiol 135(3):1798-1808

Stiller J, Nasinec V, Svoboda S, Nemcova B, Machackova T (1992) Effects of agrobacterial oncogenes in kidney vetch (Anthyllis vulneraria L.). Plant Cell Rep 11:363-367

Stiller J, Martirani L, Tuppale S, Chian RJ, Chiurazzi M, Gresshoff PM (1997) High frequency transformation and regeneration of transgenic plants in the model legume Lotus japonicus. $\mathrm{J}$ Exp Bot 48:1357-1365

Stummer BE, Smith SE, Langridge P (1995) Genetic transformation of Verticordia grandis (Myrtaceae) using wild-type Agrobacterium rhizogenes and binary Agrobacterium vectors. Plant Sci 111:51-62

Sudha CG, Obul Reddy B, Ravishankar GA, Seeni S (2003) Production of ajmalicine and ajmaline in hairy root cultures of Rauvolfia micrantha Hookf, a rare and endemic medicinal plant. Biotechnol Lett 25:631-636

Suginuma C, Akihama T (1995) Transformation of gentian with Agrobacterium rhizogenes. Acta Hort 392:153-160 
Sun, L-Y, Monneuse M-O, Martin-Tanguy J, Tepfer D (1991) Changes in flowering and accumulation of polyamines and hydroxycinnamic acid-polyamine conjugates in tobacco plants transformed by theA locus from the Ri $\mathrm{T}_{\mathrm{L}}$-DNA of Agrobacterium rhizogenes. Plant Sci 80:145-146

Suzuki M (1989) SPXX, a frequent sequence motif in gene regulatory proteins. J Mol Biol 207:61-84

Suzuki H, Fowler T, Tierney M (1993) Deletion analysis and localization of SbPRP1, a soybean cell wall protein gene, in roots of transgenic tobacco and cowpea. Plant Mol Biol 21:109-119

Suzuki K, Tanaka N, Kamada H, Yamashita I (2001) Mikimopine synthase (mis) gene on pRi1724. Gene 263:49-58

Swain SS, Rout KK, Chand PK (2012) Production of Triterpenoid Anti-cancer Compound Taraxerol in Agrobacterium-Transformed Root Cultures of Butterfly Pea (Clitoria ternatea L.). Appl Biochem Biotechnol 168(3):487-503

Talano MA, Agostini E, Medina MI, Reinoso H, Tordable Mdel C, Tigier HA, de Forchetti SM (2006) Changes in lignosuberization of cell walls of tomato hairy roots produced by salt treatment with the release of a basic peroxidase. J Plant Physiol 163:740-749

Tanaka N, Takao M, Matsumoto T (1994) Agrobacterium rhizogenes mediated transformation and regeneration of Vinca minor L. Plant Tiss Cult Lett 11:191-198

Tanaka N, Fujikawa Y, Aly MAM, Saneoka H, Fujita K, Yamashita I (2001) Proliferation and rol gene expression in hairy root lines of Egyptian clover (Trifolium alexandrinum L.). Plant Cell Tiss Org 66:175-182

Tao R, Handa T, Tamura M, Sugiura A (1994) Genetic transformation of Japanese persimmon (Diospyros kaki L.) by Agrobacterium rhizogenes wild type strain A4. J Jap Soc Hort Sci 63:283-289

Taylor BH, Amasino RM, White EW, Gordon MP (1985) T-DNA analysis of plants regenerated from hairy root tumors. Mol Gen Genet 201: 554-557

Taylor NJ, Fauquet CM (2002) Microparticle bombardment as a tool in plant science and agricultural biotechnology. DNA and Cell Biol 21(12):963-977

Tempe J, Petit A, Farrand SK (1984) Induction of cell proliferation by Agrobacterium tumafaciens and $A$. rhizogenes: a parasite's point of view D.P.S Verma and T. Hohn. Genes involved in microbe-plant interactions. Springer-Verlag, New York, pp 271-286

Tepfer D (1983) The potential uses of Agrobacterium rhizogenes in the genetic engineering of higher plants: nature got there first. In: Lurquin P, Kleinhofs A (eds) Genetic engineering in eukaryotes. Plenum, New York, pp 153-164

Tepfer D (1984) Transformation of several species of higher plants by Agrobacterium rhizogenes: sexual transmission of the transformed genotype and phenotype. Cell 37:959-967

Tepfer D (1990) Genetic transformation using Agrobacterium rhizogenes. Physiol Plant 79:140-146

Thimmaraju R, Venkatachalam L, Bhagyalakshmi N (2008) Morphometric and biochemical characterization of red beet (Beta vulgaris L.) hairy roots obtained after single and double transformations. Plant Cell Rep 27:1039-1052

Thomas MR, Rose RJ, Nolan KE (1992) Genetic transformation of Medicago truncatula using Agrobacterium with genetically modified Ri and disarmed Ti plasmids. Plant Cell Rep 11:113117

Thomashow LS, Reeves S, Thomashow MF (1984) Crown gall oncogenesis: evidence that a TDNA gene from the Agrobacterium Ti plasmid pTiA6 encodes an enzyme that catalyzes synthesis of indoleacetic acid. Proc Natl Acad Sci 81:5071-5075

Tomilov A, Tomilova N, Yoder JI (2007) Agrobacterium tumefaciens and Agrobacterium rhizogenes transformed roots of the parasitic plant Triphysaria versicolor retain parasitic competence. Planta 225(5):1059-1071

Trovato M, Mauro ML, Costantino P, Altamura MM (1997) The rolD gene from Agrobacterium rhizogenes is developmentally regulated in transgenic tobacco. Protoplasma 197:111-120

Trovato M, Maras B, Linhares F, Constantino P (2001) The plant oncogene rolD encodes a functional ornithine cyclodeaminase. Proc Natl Acad Sci 98:13449-13453

Trulson AJ, Simpson RB, Shahin EA (1986) Transformation of cucumber (Cucumis sativus L.) plants with Agrobacterium rhizogenes. Theor Appl Gene 73:11-15 
Turgut Kara N, Ari S (2008) In vitro plant regeneration from embryogenic cell suspension culture of Astragalus chrysochlorus (Leguminoseae). Afr J Biotechnol 7(9):1250-1255

Turgut Kara N, Ari S (2010) The optimization of voltage parameter for tissue electroporation in somatic embryos of Astragalus chrysochlorus (Leguminosae). Afr J Biotechnol 9(29):4584-4588

Tzfira T, Citovsky V (2000) From host recognition to T-DNA integration: the function of bacterial and plant genes in the Agrobacterium-plant cell interaction. Mol Plant Pathol 11(4):201-212

Tzfira T, Yarnitzky O, Vainstein A, Altman A (1996). Agrobacterium rhizogenes-mediated DNA transfer in Pinus halepensis Mill. Plant Cell Rep 16:26-31

Umber M, Clement B, Otten L (2005) The T-DNA oncogene A4- orf8 from Agrobacterium rhizogenes strain A4 induces abnormal growth in tobacco. Mol Plant Microbe Interact 18:205-211

Uozumi N, Kobayashi T (1997) Artificial seed production through hairy root regeneration. In: Doran PM (ed) Hairy roots: culture and applications. Harwood Academic Publishers, Amsterdam, pp 113-122

Uozumi N, Ohtake Y, Nakashimada Y, Morikawa Y, Tanaka N, Kobayashi T (1996) Efficient regeneration from GUS-transformed Ajuga hairy root. J Ferm Bioeng 81:374-378

Vain P (2007) Thirty years of plant transformation technology development. Plant Biotechnol J 5:221-229

van Altvorst AC, Bino RJ, van Dijk AJ, Lamers AMJ, Lindhout WH, Van Der Mark F, Dons JJM (1992) Effects of the introduction of Agrobacterium rhizogenes rol genes on tomato plant and flower development. Plant Sci 83:77-85

van de Velde W, Mergeay J, Holsters M, Goormachtig S (2003) Agrobacterium rhizogenes-mediated transformation of Sesbania rostrata. Plant Sci 165:1281-1288

van der Salm TPM, Van Der Toorn CJG, Bouwer R, Haenisch ten Cate CH, Dons HJM (1997) Production of rol gene transformed plants of Rosa hybrida L. and characterization of their rooting ability. Mol Breed 3:39-47

van Onckelen H, Prinsen E, Inze D, Rudelsheim P, van Lijsebettens M, Follin A, Schell J, van Montagu M, De Greef J (1986) Agrobacterium T-DNA gene codes for tryptophan 2-monooxygenase activity in tobacco crown gall cells. FEBS Lett 198:357-360

Vansuyt G, Vilaine F, Tepfer M, Rossingnol M (1992) rolA modulates the sensitivity to auxin of the protontranslocationcatalyzed by the plasmamembrane $\mathrm{H}^{+}$-ATPase in transformed tobacco. FEBS Lett 298:89-92

Veena V, Taylor CG (2007) Agrobacterium rhizogenes: recent developments and promising applications. In Vitro Cell Dev Biol Plant 43:383-403

Vilaine F, Casse-Delbart F (1987) A new vector derived from Agrobacterium rhizogenes plasmids: a micro-Ri plasmid and its use to construct a mini-Ri plasmid. Gene 55(1):105-14

Vilaine F, Charbonnier C, Casse-Delbart F (1987) Further insight concerning the $\mathrm{T}_{\mathrm{L}}$-region of the Ri plasmid of Agrobacterium rhizogenes strain A4: transfer of a $1.9 \mathrm{~kb}$ fragment $1 \mathrm{~s}$ sufficient to induce transformed roots on tobacco leaf fragments. Mol Gen Genet 210:111-115

Vinterhalter B, Orbović V, Vinterhalter D (1999) Transgenic root cultures of Gentiana punctata L. Acta Soc Bot Pol 4:275-280

Visser RGF, Hesseling-Meinders A, Jacobsen E, Nijdam H, Witholt B, Feenstra WJ (1989) Expression and inheritance of inserted markers in binary vectors carrying Agrobacterium rhizogenes transformed potato (Solanum tuberosum L.). Theor Appl Genet 78:705-14

Walton NJ, Belshaw NJ (1988) The effect of cadaverine on the formation of anabasine from lysine in hairy root cultures of Nicotiana hesperis. Plant Cell Rep 7:115-118

Wang CY, Chiao MT, Yen PJ, Huang WC, Hou CC, Chien SC, Yeh KC, Yang WC, Shyur LF, Yang NS (2006) Modulatory effects of Echinacea purpurea extracts on human dendritic cells: a celland gene-based study. Genomics 88:801-808

Ward DV, Zambryski P (2001) The six functions of Agrobacterium VirE2. Proc Natl Acad Sci USA 98:385-386

Weising K, Kahl G (1996) Natural genetic engineering of plant cells: the molecular biology of crown gall and hairy root disease. World J Microbiol Biotechnol 2:327-351 
Weller SA, Stead DE (2002) Detection of root mat associated Agrobacterium strains from plant material and other sample types by post-enrichment TaqMan PCR. J Appl Microbiol 92:118-126

Weller SA, Stead DE, Young JPW (2005) Induction of root-mat symptoms on cucumber plants by Rhizobium, but not by Ochrobactrum or Sinorhizobium, harbouring a cucumopine Ri plasmid. Plant Pathol 54:799-805

White LO (1972) The taxonomy of the crown gall organism Agrobacterium tumefaciens and its relationship to Rhizobia and to other Agrobacterium. J Gen Microbiol 72:565-574

White FF, Ghidossi G, Gordon MP, Nester EW (1982) Tumor induction by Agrobacterium rhizogenes involves the transfer of plasmid DNA to the plant genome. Proc Natl Acad Sci USA 79:3193-3197

White FF, Taylo BH, Huffman GA, Gordon MP, Nesterr EW (1985) Molecular and genetic analysis of the transferred DNA regions of the root-inducing plasmid of Agrobacterium rhizogenes. J Bacteriol 164(1):33-44

Willems A, Collins MD (1993) Phylogenetic analysis of Rhizobia and Agrobacteria based on 16S rRNA gene sequences. Intl J Syst Bacteriol 43:305-313

Willmitzer L, Sanchez-Serrano J, Buschfeld E, Schell J (1982) DNA from Agrobacterium rhizogenes is transferred to and expressed in axenic hairy root plant tissues. Mol Gen Genet 186:16-22

Willmitzer L, Dhaese P, Schreier PH, Schmalenbach W, Van Montagu M, Schell J (1983) Size, location and polarity of T-DNA-encoded transcripts in nopaline crown gall tumors, common transcripts in octopine and nopaline tumors. Cell 32(4):1045-1056

Woese CR, Gupta R, Hahn CM, Zillig W, Tu J (1984) The phylogenetic relationships of three sulfur-dependent archaebacteria. Syst Appl Microbiol 5:97-105

Yadav NS, Van Der Leyden J, Bennett DR, Barnes WM, Chilton M-D (1982) Short direct repeats flank the T-DNA on a nopaline Ti plasmid. Proc Natl Acad Sci 79:6322-6326

Yamada T, Palm CJ, Brooks B, Kosuge T (1985) Nucleotide sequences of the Pseudomonas savastanoi indole acetic acid gene show homology with Agrobacterium tumefaciens T-DNA. Proc Natl Acad Sci 82:6522-6526

Yamazaki M, Son L, Hayashi T, Morita N, Asamizu T, Mourakoshi I, Saito K (1996) Transgenic fertile Scoparia dulcis L., a folk medicinal plant, conferred with a herbicide-resistant trait using an Ri binary vector. Plant Cell Rep 15:317-321

Yang DC, Choi YE (2000) Production of transgenic plants via Agrobacterium rhizogenes-mediated transformation of Panax ginseng. Plant Cell Rep 19(5):491-496

Yasuda H, Tada Y, Hayashi Y, Jomori T, Takaiwa F (2005) Expression of the small peptide GLP-1 in transgenic plants. Transgenic Res 14(5):677-684

Yibrah HS, Grönroos R, Lindroth A, Franzén H, Clapham D, von Arnold S (1996) Agrobacterium rhizogenes-mediated induction of adventitious rooting from Pinus contorta hypocotyls and the effect of 5-azacytidine on transgene activity. Transgenic Res 5:75-85

Yokoyama R, Hirose T, Fujii N, Aspuria ET, Kato A, Uchimiya H (1994) The rolC promoter of Agrobacterium rhizogenes Ri plasmid is activated by sucrose in transgenic tobacco plants. Mol Gen Genet 244:15-22

Yoshimatsu K, Shimomura K (1992) Transformation of opium poppy (Papaver somniferum L.) with Agrobacterium rhizogenes MAFF 03-01724. Plant Cell Rep 11:132-136

Yusibov VM, Steck TR, Gupta V, Gelvin SB (1994) Association of single-stranded transferred DNA from Agrobacterium tumefaciens with tobacco cells. Proc Natl Acad Sci USA 91:2994-2998

Zambryski P, Joos H, Genetello C, Leemans J, Van Montagu M, Schell J (1983) Ti-plasmid vector for the introduction of DNA into plant cells without alteration of their normal regeneration capacity. EMBO J 2:2143-2150

Zdravkovic-Korac S, Muhovski Y, Druart PH, Calic D, Radojevic LJ (2004) Agrobacterium rhizogenes-mediated DNA transfer to Aesculus hippocastanum L. and the regeneration of transformed plants. Plant Cell Rep 22:698-704 
Zhan XC, Jones DA, Kerr A (1988) Regeneration of flax plants transformed by Agrobacterium rhizogenes. Plant Mol Biol 11:551-559

Zhu JP, Oger M, Schrammeijer B, Hooykaas PJJ, Farrand SK, Winans SC (2000) The bases of crown gall tumorigenesis. J Bacteriol 182:3885-3895

Ziemienowicz A, Merkle T, Schoumacher F, Hohn B, Rossi L (2001) Import of Agrobacterium T-DNA into plant nuclei: two distinct functions of VirD2 and VirE2 proteins. Plant Cell 13:369-383

Zuker A, Tzfira T, Scovel G, Ovadis M, Shklarman E, Itzhaki H (2001) rolC-transgenic carnation with improved agronomic traits: quantitative and qualitative analyses of greenhouse-grown plants. J Am Soc Hortic Sci 126:13-18

Zupan JR, Zambryski P, Citovsky V (1996) Agrobacterium VirE2 protein mediates nuclear uptake of single-stranded DNA in plant cells. Proc Natl Acad Sci 93:2392-2397 